\title{
You Can't Always Get What You Want: Trade-Size Clustering and Quantity Choice in Liquidity
}

\author{
Pamela C. Moulton* \\ Published in 2005 in the Journal of Financial Economics 78(1), pp. 89-119.
}

\begin{abstract}
This paper examines whether investors care more about trading their exact quantity demands at some times than at others. Using a new data set of foreign-exchange transactions, I find that customers trade more precise quantities at quarter-end, as evidenced by less trade-size clustering. Customers trade more odd lots and fewer round lots, while the number of trades and total volume are not significantly changed. I also find that the price impact of order flow is greater when customers care more about trading precise quantities. This work sheds new light on trade-size clustering and offers a potential explanation for time-series and cross-sectional variations in common liquidity measures.
\end{abstract}

JEL classification: D4; G12; G14

Keywords: Liquidity; Trade-size clustering; Round lots; Odd lots; Order flow; Price impact; Foreign exchange

\footnotetext{
${ }^{*}$ New York Stock Exchange, 11 Wall Street, $17^{\text {th }}$ Floor, New York, NY 10005. Phone: (212) 656-5508; Fax: (212) 656-2401; Email: pmoulton@nyse.com I thank Stephen Brown, Laurie Simon Hodrick, Kose John, Woodrow Johnson, Charles Jones, Lynn Kugele, Jeffrey Mercer, Ed Nelling, Elizabeth Odders-White, Carol Osler, Marios Panayides, Jörg Rocholl, Patrik Sandås, Virginia Sarria-Allende, Subra Subrahmanyam, Suresh Sundaresan, Li Wei, an anonymous referee, and seminar participants at Columbia Business School, the Bank of Canada, Drexel University, the Federal Reserve Bank of New York, the Federal Reserve Board, the New York Stock Exchange, St. John's University, and the 2004 Financial Management Association and Southwest Finance Association meetings for helpful comments and suggestions. I also thank Melissa Chak for excellent research assistance. I acknowledge the generosity of the Center for International Business Education at Columbia University. The opinions expressed in this paper do not necessarily reflect the opinions of the members, officers, or employees of the New York Stock Exchange.
} 


\section{Introduction}

A simple definition of liquidity is how easily a transaction can be executed. In a perfectly liquid market a trader can trade his desired quantity, immediately, without moving the market price. If liquidity is less than perfect, the trader must sacrifice on one or more of these three dimensions, perhaps trading a different amount, over time, and/or at a less-favorable price.

In this empirical work I examine whether traders' willingness to sacrifice on the quantity dimension varies over time. This is an important step in determining whether all three dimensions need to be considered in measuring an asset's liquidity. Much theoretical work on liquidity assumes that traders never choose to trade a quantity other than their exogenous demand. For example, Black (1971) describes liquidity as the ability to trade at a good price over time or a worse price immediately, but assumes that traders always trade exactly their desired quantities in total. Models including Copeland and Galai (1983), Kyle (1985), and Easley and O'Hara (1987) maintain the assumption that uninformed traders must trade their exogenous quantity demands.

If traders always trade their desired quantities, time-price trade-offs may be sufficient to explain differences in liquidity over time and across assets. But when all traders are allowed to rationally choose on which dimensions to sacrifice, time-price trade-offs may not be sufficient to summarize the liquidity of an asset. For example, in a model with all traders allowed to rationally choose on which dimensions to sacrifice, Hodrick and Moulton (2003) show that quantity, time, and price are not always substitutes. ${ }^{1}$ Time-price trade-offs can look significantly different when traders are willing to sacrifice along the quantity dimension versus when they are not.

I propose that the ends of fiscal quarters are natural times when investors may have a 
stronger desire to satisfy their quantity demands. This could be due to quarter-end window dressing or simply a heightened desire to have portfolios fully aligned with their stated objectives at times when internal and external scrutiny may be greater. I test whether investors care more about trading exactly their desired quantities by examining how their quantity choices change at quarter-end. If investors with heterogeneous exogenous demands all experience an increase in their desire to satisfy their demands at quarter-end, the market should witness more distinct quantities traded, or less trade-size clustering. More formally, I sse the following empirical implication from Hodrick and Moulton (2003): in a market with many heterogeneous uninformed investors, an asset will trade at more distinct quantities when the quantity dimension is more binding. "At more distinct quantities" refers to trades of more different quantities taking place, not necessarily more trades or more total volume. ${ }^{2}$ In this model the quantity dimension is "more binding" when investors care more about trading exactly their quantity demands, so they are less willing to sacrifice on quantity to get a better price or to trade more quickly.

Using a new data set of foreign-exchange customer transactions, I find that the number of distinct quantities traded increases significantly at quarter-ends, and not merely at fiscal yearends. This evidence suggests that the quantity dimension is indeed more binding at some times, as customers exhibit an increased desire to trade precisely their quantity demands. An increase in order-splitting or exogenous demands appears ess likely to explain the decrease in trade-size clustering at quarter-end for several reasons. Neither the number of trades nor the total volume increases significantly at quarter-end, and there is no significant change in the distribution of

\footnotetext{
1 Models in which uninformed investors are allowed more limited discretion over their trading choices include Admati and Pfleiderer (1988), Foster and Viswanathan (1990), Glosten and Milgrom (1985), and Spiegel and Subrahmanyam (1992).

${ }^{2}$ For example, consider a day with five trades and total volume of 100 units. If there are five trades of 20 units each, the asset has traded at only one quantity, but if there are two trades of 35 units and three trades of 10 units, the asset has traded at two quantities.
} 
quantities traded. The increase in the number of quantities traded arises from investors' trading more odd lots and fewer round lots, resulting in less trade-size clustering, at quarter-end. Trading activity in currency futures, a possible substitute asset, is also consistent with customers' caring more about satisfying their exogenous demands, rather than their experiencing a change in those demands, at quarter-end.

I also find that when traders care more about trading precise quantities the price impact of trades is greater, suggesting that they sacrifice more on the price dimension. The extent to which traders care about satisfying their quantity demands may explain some of the cross-sectional and time-series variations in common liquidity measures. For example, Breen, Hodrick, and Koraczyk (2002) find that price impact varies considerably cross-sectionally, and Chordia, Roll, and Subrahmanyam (2000) document time variation in several common liquidity measures.

This work offers some of the first direct analysis of trade-size clustering. Many researchers have documented price clustering beyond the minimum tick size in equity markets; see, for example, Christie and Schultz (1994), Grossman et al. (1997), and Kandel, Sarig, and Wohl (2001). In the foreign-exchange market, Bessembinder (1994) documents price clustering in quotes and Osler (2003) finds price clustering in price-contingent orders. In a recent paper, Alexander and Peterson (2004) document trade-size clustering in equities. My analysis uncovers clustering in foreign-exchange trade sizes and finds that trades generally cluster at round sizes, just as the price-clustering literature finds that prices cluster at round numbers. This trade-size clustering is reduced at the end of calendar quarters, when investors appear to care more about trading precise amounts.

This work is also complementary to the empirical literature linking trading activity to the choices of informed traders. Chan and Fong (2000), Conrad, Hameed, and Niden (1994), Jones, 
Kaul, and Lipson (1994), and McInish and Wood (1991) show that the number of transactions is related to asset returns and volatility in ways suggestive of informed traders' activity in a market. Other researchers focus on the role of trade size in market liquidity. For example, Barclay and Warner (1993) find that medium-size trades tend to have the greatest price impact, suggesting that informed traders concentrate their trading in intermediate sizes. Brennan and Subrahmanyam (1998) and Glosten and Harris (1988) find that average trade size is related to Kyle's (1985) market depth parameter, again measuring the impact of informed traders. My analysis complements these studies by examining a feature of trading activity, the number of distinct quantities traded, that likely reflects uninformed traders' choices. Together these analyses provide a richer understanding of observed patterns of trade.

The organization of the paper is as follows. Section 2 reviews the theoretical liquidity model of Hodrick and Moulton (2003). Section 3 develops the econometric model. Section 4 discusses the data. Section 5 presents the results and several robustness checks. Section 6 examines how a more-binding quantity dimension affects the price dimension. Section 7 concludes and outlines future work. The Appendix presents additional robustness checks.

\section{Theory}

This section summarizes the intuition, setup, and selected results of the one-period version of the liquidity model developed by Hodrick and Moulton (2003), henceforth HM, under the assumption of uninformed investors with heterogeneous quantity demands.

An asset is considered perfectly liquid if one can trade the quantity one desires, immediately, at a price not worse than the uninformed expected value. Deviations from perfect liquidity in any of these three dimensions, quantity, time, and price, impose shadow costs on the trader. The key innovation of HM is that uninformed investors do not have to obtain exactly their 
desired quantities. This is in contrast to most of the previous literature, which follows Black's (1971) description of liquidity as the trade-off between price and immediacy, assuming that a trader always gets his desired quantity. By taking the shadow cost on quantity seriously, HM show that the mere existence of multiple quantities does not ensure that all quantities are traded in equilibrium. In particular, the equilibrium number of quantities traded in a market with heterogeneous uninformed investors is increasing in the uninformed investors' desire to satisfy their quantity demands. This is the empirical prediction used in this paper.

\subsection{Model summary}

In the HM one-period model there are three types of risk-neutral agents. One is a liquidity provider who sets a price and quantity schedule for an asset. Depending on the asset, this liquidity provider may be a specialist, a market maker, a dealer, or anyone who quotes a price for a particular quantity and stands ready to trade at that price. There are also two types of potential liquidity demanders, an informed trader and multiple uninformed investors. The informed and uninformed liquidity demanders are called "trader" and "investors", respectively, purely for expositional simplicity; no assumption is made about their investment horizons. The informed trader represents fraction $\alpha$ of the liquidity demanders, $0 \leq \alpha \leq 1$, and the uninformed investors represent fraction $(1-\alpha)$. The informed trader and the uninformed investors all rationally choose whether and what quantity to trade, but if they choose to trade they must trade at the price set by the liquidity provider for that quantity.

HM consider a market in which prices may be quoted for a large and a small quantity on each side of the market. On the ask side the liquidity provider sells and the liquidity demander buys, and on the bid side the liquidity provider buys and the liquidity demander sells. The large and small quantities are denoted $\mathrm{Q}^{\mathrm{AL}}$ and $\mathrm{Q}^{\mathrm{AS}}$ on the ask side and $\mathrm{Q}^{\mathrm{BL}}$ and $\mathrm{Q}^{\mathrm{BS}}$ on the bid side, 
with $\mathrm{Q}^{\mathrm{AL}}>\mathrm{Q}^{\mathrm{AS}}>0>\mathrm{Q}^{\mathrm{BS}}>\mathrm{Q}^{\mathrm{BL}}$, consistent with the prior literature. The prices corresponding to these quantities are denoted $\mathrm{P}^{\mathrm{AL}}, \mathrm{P}^{\mathrm{AS}}, \mathrm{P}^{\mathrm{BS}}$ and $\mathrm{P}^{\mathrm{BL}}$. The true value of the asset is denoted $\mathrm{P}^{*}$ and is known by the informed trader before trading begins. For expositional simplicity, a binary distribution for the asset's true value is assumed here, with $\delta$ the probability that $\mathrm{P}^{*}=\mathrm{P}_{\mathrm{L}}$ (low value) and (1- $\delta$ ) the probability that $\mathrm{P}^{*}=\mathrm{P}_{\mathrm{H}}$ (high value).

Each uninformed investor is motivated to trade by an exogenous demand for quantity, Q*, which the uninformed investor knows before trading begins. Note that $\mathrm{Q}^{*}$ can equal zero in this model; in other words, an uninformed investor may have no exogenous demand to trade. Even when her $\mathrm{Q}^{*}$ is non-zero, an uninformed investor optimally chooses whether to trade her Q* or another quantity, including zero, as detailed below.

All three types of agents in the HM model are rational maximizers. The liquidity provider is uninformed and cannot distinguish between the informed trader and the uninformed investors. The liquidity provider is modeled as a single agent, but (unmodeled) competition or the threat of competition is assumed to drive his expected profit to zero on each trade. Zero inventory and order-processing costs are also assumed for simplicity. The liquidity provider solves the following maximization: ${ }^{3}$

$$
\begin{gathered}
\max _{\mathrm{P}^{A S}, \mathrm{P}^{\mathrm{AL}}, \mathrm{P}^{\mathrm{BS}}, \mathrm{P}^{\mathrm{BL}}}(1-\alpha)\left[\pi^{\mathrm{AS}} \mathrm{Q}^{\mathrm{AS}}\left(\mathrm{P}^{\mathrm{AS}}-\mathrm{E}\right)+\pi^{\mathrm{AL}} \mathrm{Q}^{\mathrm{AL}}\left(\mathrm{P}^{\mathrm{AL}}-\mathrm{E}\right)+\pi^{\mathrm{BS}} \mathrm{Q}^{\mathrm{BS}}\left(\mathrm{P}^{\mathrm{BS}}-\mathrm{E}\right)+\pi^{\mathrm{BL}} \mathrm{Q}^{\mathrm{BL}}\left(\mathrm{P}^{\mathrm{BL}}-\mathrm{E}\right)\right] \\
-\alpha\left[(1-\delta)\left\{\phi^{\mathrm{AS} / \mathrm{PH}} \mathrm{Q}^{\mathrm{AS}}\left(\mathrm{P}_{\mathrm{H}}-\mathrm{P}^{\mathrm{AS}}\right)+\phi^{\mathrm{AL} / \mathrm{PH}} \mathrm{Q}^{\mathrm{AL}}\left(\mathrm{P}_{\mathrm{H}^{-}}-\mathrm{P}^{\mathrm{AL}}\right)\right\}\right. \\
\left.+\delta\left\{\phi^{\mathrm{BS} / \mathrm{PL}} \mathrm{Q}^{\mathrm{BS}}\left(\mathrm{P}_{\mathrm{L}}-\mathrm{P}^{\mathrm{BS}}\right)+\phi^{\mathrm{BL} / \mathrm{PL}} \mathrm{Q}^{\mathrm{BL}}\left(\mathrm{P}_{\mathrm{L}}-\mathrm{P}^{\mathrm{BL}}\right)\right\}\right]
\end{gathered}
$$

s.t. zero expected profit per trade

where $\mathrm{E}$ is the uninformed expected value of the asset $\pi^{\mathrm{ij}}$ is the probability the uninformed chooses to trade $\mathrm{Q}^{\mathrm{ij}}$

\footnotetext{
${ }^{3}$ The liquidity provider's maximization is very reminiscent of the earlier literature, such as Copeland and Galai (1983), Glosten and Milgrom (1985), and Easley and O'Hara (1987).
} 
$\phi^{\mathrm{ij} / \mathrm{x}}$ is the probability the informed chooses to trade $\mathrm{Q}^{\mathrm{ij}}$ given $\mathrm{P}^{*}=\mathrm{x}$.

The first line of this maximization reflects the profits that the liquidity provider expects to make by trading with uninformed investors. To realize these profits the liquidity provider sets ask prices above and bid prices below the uninformed expected value. The second and third lines of the maximization capture the liquidity provider's expected losses from trading with the informed trader, since in equilibrium the informed trader trades only when ask prices are below or bid prices are above the asset's true value.

The informed trader maximizes the gain from trading on his information: ${ }^{4}$

$$
\begin{aligned}
& \max _{\mathrm{Q}^{\mathrm{ij}}} \mathrm{Q}^{\mathrm{ij}}\left(\mathrm{P}^{*}-\mathrm{P}^{\mathrm{ij}}\right) \\
& \in\left\{0, \mathrm{Q}^{\mathrm{AS}}, \mathrm{Q}^{\mathrm{AL}}, \mathrm{Q}^{\mathrm{BS}}, \mathrm{Q}^{\mathrm{BL}}\right\}
\end{aligned}
$$

The informed trader has a preference, all else equal, for larger quantities and for quantities that have prices closer to the uninformed expected value.

HM's main innovation appears in the uninformed investors' maximization:

$$
\begin{aligned}
& \max _{Q^{i j}} Q_{\left\{0, Q^{A S}, Q^{A L}, Q^{B S}, Q^{B L}\right\}}\left(E-P^{i j}\right)-\theta\left(\left|Q^{*}-Q^{i j}\right|\right) \\
& \text { where } E=\text { the uninformed expected value of the asset } \\
& Q^{*} \in\left\{0, Q^{A S}, Q^{A L}, Q^{B S}, Q^{B L}\right\}
\end{aligned}
$$

The first term captures the uninformed investors' desire for value. Value reflects their desire to transact at a price as close as possible to their expectation of the asset's value. The pain from this non-positive term is minimized when uninformed investors choose quantities that are smaller and have prices closer to the uninformed expected value. This causes uninformed investors to be less likely to trade in the presence of an informed trader. In the second term, the uninformed investors' $\theta$ reflects the intensity of their desire for satisfaction, $0 \leq \theta \leq \infty$. 
Satisfaction reflects how strongly they care about attaining their $\mathrm{Q}^{*} \mathrm{~s}$. The pain from this nonpositive term is minimized when uninformed investors choose to trade quantities equal to their Q*s. The strength of the uninformeds' desire for satisfaction, $\theta$, may be influenced by such factors as their access to substitute products and seasonal pressures. For example, an investor may have a stronger desire to trade a particular quantity to achieve a desired portfolio position near the end of a fiscal reporting period. The two shadow costs of value and satisfaction and their interaction are the key determinants of which quantities, if any, uninformed investors choose to trade in equilibrium. Heterogeneous uninformed investors are assumed to have a common intensity of desire for satisfaction (a common theta) but different exogenous demands for quantity (heterogeneous $\mathrm{Q}^{*} \mathrm{~s}$ ).

\subsection{Selected results}

The key one-period results proved in HM concern the nature of equilibrium prices, the optimal behavior of liquidity demanders, and empirical predictions about the extent of trade at various quantities in asset markets. I briefly summarize only those results that are relevant to the empirical implication used in this paper.

HM examine a rational expectations equilibrium. Equilibrium prices are optimally set to reflect the probabilistic presence of the uninformed investors and the informed trader, taking into account their relative presence in the population of liquidity demanders and their endogenous quantity choices given their $\mathrm{Q}^{*} \mathrm{~s}$ and $\mathrm{P}^{*}$. If there is no possibility of an informed trader, all prices equal the asset's uninformed expected value. If there are potentially both informed and uninformed traders, the informed trader's presence pushes ask prices above and bid prices below the uninformed expected value.

\footnotetext{
4 The informed trader's maximization is also very reminiscent of the earlier literature, such as Copeland and Galai (1983) and Easley and O'Hara (1987).
} 
In an equilibrium with an informed trader present, an uninformed investor never chooses to trade if her desire for satisfaction, theta, is zero or is low enough. The desire for satisfaction of a non-zero $\mathrm{Q}^{*}$ is the only thing that can motivate an uninformed investor to trade in the face of her negative value term.

The informed trader never chooses to trade a quantity that the uninformed investors do not have a positive probability of trading. Furthermore, if the uninformed investors are trading some non-zero quantity, the informed trader never abstains from trading altogether.

These equilibrium behaviors lead to the following empirical implication. The number of quantities traded in a market with heterogeneous uninformed investors is increasing in the uninformed investors' desire for satisfaction. At a low (or zero) desire for satisfaction, theta, the uninformed investors' satisfaction terms are not large enough to offset their value terms, so they choose not to trade, leading to a no-trade equilibrium. At a somewhat higher theta, the uninformed investors' satisfaction terms begin to offset their value terms, causing them to choose to trade but not all quantities. This leads to a one-quantity equilibrium. Finally, at a very high (or infinite) theta, the uninformed investors' satisfaction terms dominate their value terms, and they choose to trade exactly their $\mathrm{Q}^{*} \mathrm{~s}$. This results in a multiple-quantity equilibrium.

Although HM model only two quantities on each side of the market, the intuition that more quantities are traded at higher desires for satisfaction extends naturally to a market with more than two possible quantities. In a richer setting with many possible quantities, the informed trader's relative presence across different quantities continues to make some quantities worse value than other quantities for the uninformed investors. A higher desire for satisfaction is required to induce the uninformed investors to trade more of the possible quantities because the value-satisfaction trade-off varies across quantities. 


\section{Empirical specification and methodology}

The ends of fiscal quarters are natural times when the quantity dimension is likely to be more binding, as investors are likely to have a stronger desire to trade specific quantities. This could be due to quarter-end window dressing or simply a heightened desire to have portfolios fully aligned with their stated objectives at times when internal and external scrutiny may be greater. Hodrick and Moulton (2003) predict that in a market with many heterogeneous uninformed investors, an asset will trade at more distinct quantities when investors have a stronger desire to satisfy their exogenous demands. "At more distinct quantities" refers to trades of more different quantities (sizes) taking place, not necessarily more trades or more total volume. For example, five trades of different size blocks constitute five sizes, while two trades of one size and three trades of another size constitute two sizes. I use foreign-exchange transaction data to test whether the number of different quantities traded is significantly higher at quarterend than at other times.

\subsection{Basic specification}

In its simplest form, I test whether the number of sizes traded rises significantly at quarter-end, controlling for the number of trades because the number of distinct sizes is closely related to the number of trades: there cannot be more sizes than trades in a day. Taking this into account suggests the following basic specification:

$$
\begin{aligned}
\text { Sizes }_{\mathrm{t}}=\alpha+\beta_{1} \mathrm{EOQ}_{\mathrm{t}}+\beta_{2} \text { Trades }_{\mathrm{t}}+\varepsilon_{\mathrm{t}} \\
\text { where } \text { Sizes }_{\mathrm{t}}=\text { number of distinct quantities traded on day } \mathrm{t} \\
\mathrm{EOQ}_{\mathrm{t}}=1 \text { if day } \mathrm{t} \text { is in end-of-quarter period, else } 0 \\
\text { Trades }_{\mathrm{t}}=\text { total number trades on day } \mathrm{t}
\end{aligned}
$$

If quarter-ends do witness an increase in customers' desire to trade specific quantities, the coefficient on the end-of-quarter indicator in Eq. (4) should be significantly positive. 


\subsection{Extended specification}

For robustness, I also consider an extended specification that includes the following additional explanatory variables that may affect size choices.

Non-end-of-quarter Month-ends: I test whether non-end-of-quarter month-ends exhibit a significant increase in the number of quantities traded. If they do not, it will help to support the interpretation of customers' experiencing an increase in desire for satisfaction versus an alternative explanation that the increase in number of quantities traded is primarily due to monthly events such as index changes. Monthly index changes map more closely to changing exogenous demands, rather than customers' increasing desire to satisfy their demands, and should affect all month-ends, not just quarter-ends.

Price Level: Perhaps when an asset trades at a price level that is widely believed to be important, trading activity increases and size choices are affected. Recent work linking liquidity and technical analysis, Osler (2003) in the foreign-exchange market and Kavajecz and OddersWhite (2003) in equities, suggests that prices' crossing major round numbers can bring about changes in trading activity.

Implied Volatility: Customers' size choices may be affected when the market is perceived to be more volatile, as reflected in short-dated implied volatility.

9/11 Period: The 9/11/2001 terrorist attacks may provide insight into how extreme uncertainty affects size choices. Many banks' operations were impeded on that day, so the fourday period beginning on $9 / 11 / 2001$ is examined.

Futures Expiration: Size choices in an asset market may be affected by the changes in trading activity on the last trading day of a related futures contract, as documented by Brown and Steenbeek (2001). 
Central Bank Interventions: I use foreign-exchange transactions in my empirical analysis, and in this market central bank interventions may affect size choices.

Incorporating these explanatory variables leads to the following extended specification:

$$
\begin{aligned}
& \text { Sizes }_{t}=\alpha+\beta_{1} \text { EOQ }_{t}+\beta_{2} \text { Trades }_{t}+\beta_{3} \text { NonEOQ }_{t}+\beta_{4} \text { PriceLeve }_{t}+\beta_{5} \text { ImpVol }_{t} \\
& +\beta_{6} \text { Period9/11 } 1 \mathrm{t}+\beta_{7} \text { FutExp }_{\mathrm{t}}+\beta_{8} \mathrm{CBI}_{\mathrm{t}}+\varepsilon_{\mathrm{t}} \\
& \text { where Non-EOQ } \mathrm{E}_{\mathrm{t}}=1 \text { if day } \mathrm{t} \text { is in non-end-of-quarter month-end period, } \\
& \text { else } 0 \\
& \text { PriceLeve }_{\mathrm{t}}=1 \text { if major price level is hit on day } \mathrm{t} \text {, else } 0 \\
& \operatorname{ImpVol}_{\mathrm{t}}=\text { implied volatility on day } \mathrm{t} \\
& \text { Period } 9 / 11_{\mathrm{t}}=1 \text { if day } \mathrm{t} \text { is in } 9 / 11 \text { period, else } 0 \\
& \text { FutExp }_{\mathrm{t}}=1 \text { if day } \mathrm{t} \text { is a futures expiration date, else } 0 \\
& \mathrm{CBI}_{\mathrm{t}}=1 \text { if there is central bank intervention on day } \mathrm{t} \text {, else } 0
\end{aligned}
$$

If quarter-ends witness an increase in customers' desire to trade specific quantities, the coefficient on the end-of-quarter indicator in Eq. (5) should be significantly positive. Furthermore, an insignificant coefficient on the non-end-of-quarter month-end indicator would suggest that it is not just monthly index-related increases in customers' exogenous demands, but also their increasing desire to satisfy those exogenous demands at quarter-end, which lead to the increase in quantities traded.

\subsection{Econometric methodology}

I estimate Eq. (4) and Eq. (5) separately for each currency using ordinary least squares regression. ${ }^{5}$ In preliminary analysis both equations display evidence of autocorrelation, with Durbin-Watson statistics ranging from 1.2 to 1.9 . Preliminary analysis also reveals some heteroskedasticity in the residuals. Newey-West standard errors with five lags are employed to

\footnotetext{
${ }^{5}$ As a robustness check, a seemingly unrelated regressions model was estimated for all currencies jointly and for two sub-groups, the three most active and the three less active currencies. Results are qualitatively similar and are available on request.
} 
address these two issues. ${ }^{6}$

\section{Data}

I use spot foreign-exchange customer transaction data from a major foreign-exchange dealer bank in my empirical tests. This data set is well-suited to the analysis for several reasons. First, foreign exchange is traded by a highly heterogeneous set of customers, including corporates, equity investors, fixed income investors, mutual funds, pension funds, and hedge funds, making this a promising asset class for testing an empirical implication that involves investor heterogeneity. Second, the simplicity of foreign exchange minimizes some types of noise, such as might arise from changes in private information or financing terms. Third, foreign exchange is a very active market and this bank executes many transactions every day with a wide range of customer types.

\subsection{Transaction data}

The main data set consists of spot foreign-exchange transactions for six major currency pairs between one bank and its customers from January 2000 to December 2002. The bank is one of the top three foreign-exchange dealers globally and has a large and diverse customer base. Unlike in many other asset markets, customer-dealer trades in the foreign-exchange market are visible only to the customer and the bank involved in the transaction. Banks view their customer order flow as highly proprietary and are typically reluctant to make it publicly available. The only other foreign-exchange customer trade data used in the literature to date are qualitatively different from this data set. For example, Lyons (1995) uses transaction-level data on one week of U.S. dollar/Deutschemark trades, but his sample includes no customer trades. Yao's (1997) transaction-level data from a bank include customer as well as interdealer trades, but his sample

\footnotetext{
${ }^{6}$ Both the number of sizes and the number of trades per day show an upward trend over the period, but augmented Dickey-Fuller and Phillips-Perron unit root tests strongly reject the hypothesis of a unit root.
} 
is limited to one currency pair and a 25-day period in 1995. Fan and Lyons (2003) obtain a multi-year sample of customer transaction data for two currency pairs from a top-three foreignexchange dealer bank, but their data are aggregated on a daily basis so no transaction-level analysis is possible. Osler (2003) also uses foreign-exchange customer data from a bank, but her focus is orders rather than transactions.

The sample employed here includes spot foreign-exchange transactions for the six most actively traded currency pairs, referred to henceforth as the major currencies: the euro, Japanese yen, British pound, Australian dollar, Swiss franc, and Canadian dollar, all versus the U.S. dollar. According to the Bank for International Settlements (BIS) Triennial Central Bank Survey (2002) on foreign-exchange activity, these six currency pairs account for $94 \%$ of all foreign-exchange trading. The original data set included about 1.5 million transactions, of which 3,714 transactions (about $0.25 \%$ ) were dropped because of incomplete information. The total dollar volume of transactions in the final sample is about $\$ 9.7$ trillion. Transactions are date-stamped but not timestamped and are not ordered sequentially, so it is not possible to determine in what order the transactions occurred within a day. This precludes an examination of intraday time periods, which would also be interesting.

My empirical tests focus on the number of quantities traded each day in each currency pair. Because foreign-exchange rates vary intraday, it is not sufficient to identify all trades for the same U.S. dollar amount, for example, as being one size. Transactions are considered to be the same size if their traded amounts match on either side of the currency pair. For example, a day in which the following trades occurred would be summarized as having five trades, with three sizes traded. 


\begin{tabular}{llll}
$\begin{array}{l}\text { Transaction } \\
\text { Number }\end{array}$ & USD Amount & & EUR Amount \\
\cline { 2 - 4 } & $\$ 100$ & $€ 102$ & \\
2 & $\$ 49$ & $€ 50$ & \\
3 & $\$ 100$ & $€ 101 \quad$ (same USD size as Transaction \#1) \\
4 & $\$ 48$ & $€ 50 \quad$ (same EUR size as Transaction \#2) \\
5 & $\$ 50$ & $€ 51$ &
\end{tabular}

Total: 5 trades, 3 sizes

Customers' fiscal quarter-ends are not observable in this data set, so I use calendar quarter-ends as a proxy for fiscal quarter-ends. Although customers from different countries have different fiscal year-ends (for example, March in Japan, June in Australia and New Zealand, December in the U.S. and Europe), the bank confirms that calendar quarter-ends coincide with fiscal quarter-ends for most customers in the data set. I used a separate data set from the same bank, consisting of customer transactions in three minor currencies (Swedish krona, New Zealand dollar, and Norwegian krone versus U.S. dollar), to choose the length of the end-ofquarter period. The length of the end-of-quarter period may be crucial to this analysis; using a separate data set to select the period length minimizes modelselection and inadvertent datasnooping biases in the formal analysis of the six major currencies. While the last day of the quarter is a reasonable window, my prior was that either the last week or the last two weeks of the quarter would be the most relevant window. For example, the financial press generally begins reporting Japanese year-end repatriation flows affecting asset markets around the middle of March; see, for example, Downey (2002). Analysis of the minor currency data set showed that the strongest relation arises when the end-of-quarter period is defined as the last two weeks of the quarter, so a two-week end-of-quarter period is used in the analysis below.

The main limitation of this transaction data set is that it reflects the trading activity of 
only one bank, which may or may not be representative of the entire foreign-exchange market. The BIS Triennial Central Bank Survey (2002) on foreign-exchange activity provides some perspective on the representativeness of this bank's transactions. The BIS (2002) reports that from five to 18 banks in each country account for $75 \%$ of the foreign-exchange trading activity. This bank would be included in that group in every major trading center. The breakdown of this bank's trading activity among the six major currencies mirrors that of the market as a whole, as detailed in the BIS (2002) survey, suggesting that this bank is not an outlier at least in these readily observable dimensions.

\subsection{Market data}

The transaction data set described above is supplemented with market data from several sources. Implied volatilities for one-month at-the-money options on the underlying currencies are from the same bank. Daily open, high, low, and close exchange rates are from Bloomberg. Currency futures information is from the Chicago Mercantile Exchange. Central bank intervention dates are assembled from central bank websites and press reports, for example, Reuters (2003).

\subsection{Descriptive statistics}

Table 1 shows that both the number of trades per day and the number of sizes traded per day in each currency varies widely within the period. Furthermore, although all six are major currencies, there is considerable cross-sectional variation in their activity levels. For example, the euro has about double the activity of the British pound in this sample, and the euro, Japanese yen, and British pound collectively account for about $80 \%$ of the sample in terms of total trades and total dollar volume.

The price level indicator used in this analysis is motivated by the findings of Osler (2003) 
that foreign-exchange price-contingent orders tend to cluster around prices ending in zeros. The price level indicator is set equal to one on days when the currency's price hits or crosses a price ending in two zeros. For example, if the Japanese yen hits or crosses 119.00, its price level indicator is set to one on that day. Similarly, if the Australian dollar hits or crosses 0.5900, its price level indicator is set equal to one on that day. On average, about $80 \%$ of the daily observations in each currency have a price level indicator equal to one.

\section{Results}

This section first presents the results from estimating the basic regression equation to determine whether more sizes are traded at quarter-ends. It then presents several robustness checks. The section concludes with an examination of whether the more-binding quantity dimension at quarter-end is driven by changes in exogenous demands or changes in the desire for satisfaction.

\subsection{Results from the basic specification}

Panel A of Table 2 displays the results from estimating Eq. (4), in which the number of sizes traded per day is regressed on the end-of-quarter indicator and the number of trades per day. The results indicate that more sizes tend to trade at the end of calendar quarters after controlling for the number of trades in a day. The coefficients on the end-of-quarter indicator are statistically significant, at the $1 \%$ level for the Japanese yen, British pound, Swiss franc, and Canadian dollar, the 5\% level for the euro, and the $10 \%$ level for the Australian dollar. Even adjusting the test size for the six non-overlapping two-week periods in each quarter with a Bonferroni or Sidak adjustment, four of the six currencies' coefficient estimates are significant at the $5 \%$ level or better. The coefficients on the end-of-quarter indicator are also economically significant. For example, there are about 14 more sizes traded per day in the British pound during 
the end-of-quarter period, all else equal. For a sense of the economic significance, recall that over the entire sample the British pound traded an average of 213 sizes per day.

\subsection{Robustness checks}

To check the robustness of the results from the basic specification, I consider several alternative specifications. First, Eq. (5) provides some insight into how other factors influence size choices. To determine whether the observed size effect is due to quarter-end or due to the aggregation of year-end behavior of customers with different fiscal year-ends, I analyze subsets of trades for customers with different fiscal year-ends. Finally, I examine whether the results hold across customer-type sub-groups. The results are also robust to quadratic and log specifications; see Appendix for results.

\subsubsection{Extended specification}

Panel B of Table 2 displays the results from estimating Eq. (5), in which the number of sizes traded per day is regressed on a larger set of potential explanatory variables. Overall, the results from the basic specification are robust to the inclusion of these additional explanatory variables. The coefficients on the end-of-quarter indicator are little changed in both magnitude and significance, while several of the added explanatory variables shed more light on the motivations behind trading more versus fewer sizes.

The non-end-of-quarter month-end indicator is insignificant in five of the six currencies, suggesting that the increase in number of sizes traded at quarter-end is not simply a reflection of monthly events such as index changes.

The price level indicator is weakly significant in the euro and the Japanese yen, and in both cases it appears that when the currency crosses a major level fewer sizes are traded, all else equal. This fits well with the intuition of Osler (2003), who shows that foreign-exchange stop- 
loss and take-profit orders tend to cluster at round prices. If primarily technical traders place these orders, they are very likely to be for standard sizes and thus reduce the number of sizes traded, after controlling for the total number of trades. That this variable is significant for only the euro and the Japanese yen may be due to greater participation of technical traders in the two largest currencies than in the smaller currencies. Using two price level indicators, for prices ending in two and three zeros, in the extended regression yields qualitatively similar results, with larger coefficients on the three-zero price level indicator than on the two-zero price level indicator; results available on request.

The four-day period beginning on 9/11 witnessed a significant decrease in the number of sizes traded in four of the six currencies. One possible explanation is that the extreme uncertainty brought about by the terrorist attacks caused customers to be less concerned with trading specific quantities and instead to focus on trading quickly. Furthermore, the composition of customers trading may have been different during this period, representing a change in the exogenous desires to trade as well. Such changes in customer composition are not statistically detectable among the broad customer categories dentified by the bank, suggesting that changes, if any, occurred within customer categories. Implied volatility presents a more mixed picture, with higher volatility associated with more sizes traded in three currencies and fewer sizes traded in the AUD.

Futures expiration dates have a significant impact on the number of sizes traded in only one of the six currencies. In the Australian dollar, futures expiration tends to be associated with fewer sizes traded in the spot market, perhaps suggesting a higher concentration of uniform size trades on those days to match contract round lots.

Central bank intervention dates are insignificant at conventional levels in this sample. 
There are two plausible explanations for the failure of central bank intervention to have a broader effect on size choices. First, there was very little central bank intervention in the currency markets during the January 2000 to December 2002 period. The Japanese yen witnessed the most intervention, 18 of the 22 occurrences. Second, the price level and volatility measures may capture most of the effect of central bank intervention on trading activity, as suggested by Dominguez (1998). Using two central bank intervention indicators, one for interventions involving both sides of a currency pair and the other when only one side is involved, yields qualitatively similar results; results available on request.

\subsubsection{Year-end analysis}

I motivated the empirical specification by suggesting that customers have a heightened desire to trade specific amounts at quarter-end. An alternative explanation is that these pressures arise primarily at fiscal year-end and appear to be a quarter-end effect because of the aggregation of trades from customers with different fiscal year-ends. For example, fiscal year-end is December for most U.S. and European customers, March for most Japanese customers, and June for most Australian customers. Customer domicile is an imperfect proxy for a customer's fiscal year-end, but it is the best proxy available in this data set.

Customer domicile information is available for about $75 \%$ of the trades in the transaction data set. This information is used to create three subsets, for customers with fiscal year-ends in December, March, and June. The December year-end subset is the largest, with about $68 \%$ of the transaction data set. The March and June year-end subsets are much smaller, and in each case only one currency, the Japanese yen for March fiscal year-end and the Australian dollar for June fiscal year-end, has enough trades to allow meaningful analysis. Other currencies have trades on too few days and too few trades per day. For example, less than $1 \%$ of all Canadian dollar trades 
involve customers with March fiscal year-ends (customers domiciled in Japan).

Table 3 displays regression results for the fiscal year-end subsets. Panel A shows the results from estimating the basic specification, Eq. (4). These results are qualitatively similar to those obtained on the entire transaction data set: the coefficients on the quarter-end indicators are positive and significant for most currencies. Panel B displays the results from estimating a regression in which one indicator is used for the fiscal year-end and another is used for the other three quarter-ends. The results in Panel B suggest that the quarter-end effect is not simply a reflection of year-end effects aggregated across customers with different year-ends. The coefficients on non-year-end end-of-quarter indicators are positive and significant overall. The coefficients on the year-end indicators generally lack significance at conventional levels, probably because there are only three year-end periods in the sample.

\subsubsection{Customer-type analysis}

One of the attractions of using foreign-exchange data in this empirical study is that foreign-exchange customers are highly heterogeneous and therefore would be expected to have highly heterogeneous quantity demands. In this section I examine whether the quarter-end increase in the number of sizes traded is driven by one customer type, all customer types, or the aggregation across customer types.

The bank classifies customer types using five codes, corresponding to corporate hedgers, mutual funds, commodity trading advisers (CTAs), hedge funds, and relative value traders. Other customer types, such as pension funds and proprietary traders, are classified into these five groups according to their trading styles. Customer codes are available for about $80 \%$ of the sixcurrency sample.

Table 4 displays the results from estimating Eq. (4) for each customer type individually. 
The quarter-end effects generally appear strong in the mutual fund category, as expected given mutual funds' focus on quarterly reporting and dividends. But there is evidence of a significant quarter-end effect in each of the five customer types, and no single type seems to be driving the quarter-end results of the combined sample. The distribution of customer types over time shows no significant change at quarter-end; results available on request.

\subsection{Exogenous demand versus desire for satisfaction}

The analysis above shows that more sizes are traded at the end of calendar quarters and that this result is robust to several alternative specifications, suggesting that the quantity dimension is more binding at quarter-ends. This section outlines evidence regarding whether the quantity dimension binds more because of an increase in the number of exogenous demands or because of an increase in customers' desire to satisfy their exogenous demands, which I have proposed as a likely scenario at quarter-ends. One potential explanation, that the quarterly results are driven by monthly changes in exogenous demands such as index rebalancing, is refuted by the insignificant coefficient estimates on the non-end-of-quarter end-of-month indicator in Eq. (5); see Table 2. While this result and the following additional analyses cannot completely dismiss changes in exogenous demands as an explanation, the evidence is supportive of changes in the desire for satisfaction playing a key role.

\subsubsection{Trade and size distributions}

If an increase in the number of exogenous demands is driving the binding-quantity result, there should be an increase in the number of trades at quarter-end. Furthermore, a seasonal change in exogenous demands would likely lead to a noticeable change in the distribution of sizes traded.

Table 5 displays the results of two-sided t-tests comparing trade and size characteristics 
in quarter-end versus non-quarter-end periods for each of the six currencies. The average number of trades is not significantly higher at quarter-end, suggesting that it is not purely an increase in the number of exogenous demands or increased order-splitting that leads to an increase in the number of sizes traded.

Table 5 also shows that there is no systematic difference in the average size or interquartile range of sizes traded at quarter-end. This lack of systematic change in the distribution of sizes suggests that the increase in number of sizes traded may be a result of customers' refining their size choices at quarter-end. It is possible that this refinement occurs in customers' exogenous demands, but it is not obvious why exogenous demands would be finer at quarter-end, whereas quarter-end reporting may quite naturally cause customers to refine the quantities they choose to execute given the same exogenous demands.

\subsubsection{Round versus odd sizes}

This section examines whether the increase in sizes traded at quarter-end is caused by customers' choosing to trade more round sizes, such as exact multiples of a million on one currency side, or more odd (non-round) sizes. In the foreign-exchange market round lots and odd lots are traded through the same mechanisms.

Table 6 reports coefficient estimates for the basic regression specification in Eq. (4), but with round sizes and odd sizes considered separately as the dependent variable. For this analysis a round size is defined as one that is a multiple of one million on either currency side; all other sizes are odd. A robustness check defining round sizes by thousands yields qualitatively similar results; results available on request. In four of the six currencies there is no significant increase in the number of round sizes traded at quarter-end, while five of the six currencies show a significant increase in the number of odd sizes traded at quarter-end. This indicates that the 
additional sizes traded at quarter-end are primarily odd sizes, not round sizes.

Table 7 shows that in general there are significantly fewer round-size trades and more odd-size trades at quarter-end than during non-quarter-end periods. This suggests that customers switch from trading round lots to trading odd lots at quarter-end, since Table 5 shows no statistically significant difference in the total number of trades at quarter-end.

There are several reasons that customers may generally favor round sizes over odd sizes. In examining price clustering in equity markets, Kandel, Sarig and Wohl (2001) suggest that people simply prefer round numbers. In the foreign-exchange market, Osler (2003) discusses the preference for round numbers in price-contingent order placement. Grossman et al. (1997) provide an explanation for round price clustering related to communication efficiency: the fewer digits specified, the less time it takes to communicate an order and the lower the chance of errors. This logic is as applicable to choosing quantities as it is to choosing prices. Mitchell (2001) suggests that the preference for round numbers could be related to cognitive efficiency, the ease with which shorter numbers are recalled and processed relative to longer numbers. Yule (1927) suggests a more fundamental attraction of round numbers. He finds that measurements taken by scientists in a wide range of disciplines cluster at round numbers. Yule (1927) also finds that greater precision can be induced, and rounding reduced, when the importance of the observational unit is stressed to those taking the measurements, a situation analogous to an increase in the desire for satisfaction considered here.

The observed quarter-end decrease in the number of round-size trades and increase in the number and precision of odd-size trades are consistent with a scenario in which customers with heterogeneous demands generally prefer to trade round sizes but are motivated to trade more precise sizes at quarter-end, when their desire to satisfy their exogenous demands is higher. 


\subsubsection{Futures as substitutes}

In the Hodrick and Moulton (2003) model, investors' desire for satisfaction of their exogenous demands for a particular asset should be affected by the availability and suitability of substitute assets. All else equal, the existence of substitutes should decrease the desire for satisfaction for a particular asset, since investors could choose to trade the substitute instead. Just as customers may have an increased desire to trade precise amounts at quarter-end, they may have an increased desire to trade a particular asset rather than a substitute at quarter-end. Both of these desires are encompassed by the desire for satisfaction in the Hodrick and Moulton (2003) model. The attractiveness of substitutes may also vary with relative pricing over time, but price discrepancies are rare in the foreign-exchange market and so are not explored here. In this section I examine how the trading activity in currency futures compares to that in the spot market, in order to explore the availability-of-substitutes aspect of the desire for satisfaction.

I find a weak but consistent decline in futures volume at quarter-end across all six currency contracts, ${ }^{7}$ which dovetails with the weak increase in spot volume in Table 5 . This pattern suggests that customers shift some trading activity from futures to the spot market at quarter-end. This shift may reflect a stronger desire to trade precise quantities rather than the fixed futures contract sizes. Another explanation is that futures are a less-satisfying substitute for spot foreign exchange at quarter-end. This could be due to futures' embedded interest rate

exposure, which is at a maximum in the last two weeks of every quarter when the front contract has just rolled to a three-month expiration.

If futures and spot foreign exchange were perfect substitutes they should exhibit similar changes in the number of sizes traded over time. Panel A of Table 8 presents the results from 
regressing the number of futures sizes traded daily on an end-of-quarter indicator, controlling for the number of futures trades per day. ${ }^{8}$ The only significant quarter-end effect appears in the British pound, which witnesses fewer sizes trading at quarter-end. The lack of a significant increase in futures sizes at quarter-end could be due to the standardized nature of futures, which makes them a less natural vehicle for the sort of precision trading that appears to drive the increase in spot sizes at quarter-end. Customers who care about precision, all the time or seasonally, may not view futures as a useful substitute, consistent with futures' minimal share of the total currency market. Daily futures trading volume on the Chicago Mercantile Exchange averages $\$ 100$ million to $\$ 1.5$ billion across the six currencies in April 2001, amounting to only $0.2 \%$ to $0.9 \%$ of average daily spot transaction volume for the same month, reported by the BIS (2002). For robustness, Panel B of Table 8 adds a control for the futures calendar roll period; the results are qualitatively unchanged.

Overall, the evidence from futures, viewed as imperfect substitutes for spot foreign exchange, is consistent with an increase in the desire for satisfaction at quarter-end. While quarter-end changes in exogenous demands - for example, fewer different futures exogenous demands and more different spot exogenous demands, with no substitution - cannot be ruled out, such an explanation is not as intuitive.

\section{Price dimension effects}

A key reason that market participants may care about the quantity dimension is that when customers have a stronger desire to satisfy their quantity demands, prices may move more or trades may take longer to complete, according to the model of Hodrick and Moulton (2003). An

\footnotetext{
7 Results are from regressing daily futures volume for the front two contracts on an end-of-quarter indicator, controlling for the increase in volume caused by the rolling of positions to the next contract month around futures expiration dates; results available on request.

${ }^{8}$ I thank Bob Whaley for advising me how to obtain the futures transaction data for this analysis.
} 
alternative view is that rather than trading off among quantity, price, and time, customers suffer or benefit on all three dimensions simultaneously. For example, when trading is "easy" customers may trade exactly the quantity they desire, with little price impact, immediately, and when trading is "tough" they may sacrifice on quantity, suffer greater price impact, and spread their trades over time. ${ }^{9}$ These two models suggest different empirical predictions for quarter-end price impact. Under Hodrick and Moulton (2003), price impact should be greater when customers care more about trading precise quantities at quarter-end. Under the alternative scenario price impact should be smaller at quarter-end, as customers are trading more precise amounts because it is easier to trade in general. In this section I examine whether customers suffer more or less in price terms when more precise quantities are traded at quarter-end. ${ }^{10}$

The price impact measure used here is based on the work of Evans and Lyons (2002) and Fan and Lyons (2003), who find that foreign-exchange price changes are positively related to foreign-exchange net order flow, defined as the net of buyer-initiated and seller-initiated orders. ${ }^{11}$ In this data set, all orders are customer-initiated and specify how much and which currencies are bought and sold, so foreign-exchange net order flow is directly observable, albeit for only one bank and its customers. I use the following measure of daily price impact:

$$
\text { Price Impact }=\frac{\text { Percentage Price Change }}{\text { Net Order Flow }}=\frac{\text { Percentage Price Change }}{\text { Buy Orders }- \text { Sell Orders }}
$$

Net order flow is measured in U.S. dollars, not as simply the net number of transactions. A finding that the price impact is larger at quarter-end would suggest that when customers care more about trading precise quantities (that is, the quantity dimension is more binding in the

\footnotetext{
${ }^{9}$ I thank the referee for suggesting this alternative model.

${ }^{10}$ It would also be interesting to examine whether customers spread their trades out more intraday, indicating that they sacrifice along the time dimension, or less, indicating that trading is easier, but the absence of intraday time stamps and customer identity in this data set precludes such an analysis.
} 
Hodrick and Moulton (2003) model), they sacrifice more on the price dimension. Alternatively, if customers trade more precise quantities when trading is "easy", price impact should be smaller at quarter-end.

Table 9 displays the results of ttests comparing price change, order flow, and price impact in quarter-end versus non-quarter-end periods for each currency. The first three columns show that price change, absolute price change, and net order flow are not systematically different at quarter-end. The fourth column shows that price impact is significantly larger at quarter-ends than during non-quarter-end periods for the British pound, Australian dollar, Swiss franc, and Canadian dollar. The euro exhibits a surprisingly negative price impact, most likely reflecting noise in the price impact measure from using only one bank's customer transactions with prices that are set by the entire market. Discussions with the bank indicate that over the sample period the bank's market share in the euro was likely lower than its market share in the other currencies, which may explain the higher noise level. For the euro and the Japanese yen the price impact increases at quarter-end have p-values of only $18 \%$ and $13 \%$. This lower significance may reflect the two largest currencies' superior ability to absorb more pressure in the time dimension, relative to the smaller currencies.

Regression analysis confirms that price impact is generally greater at quarter-end and shows that this effect is not explained by other variables such as trading volume or those included in Eq. (5) (see Appendix for results). Overall, the price impact results suggest that when customers care more about trading precise quantities they suffer a greater price impact to trade, consistent with the Hodrick and Moulton (2003) model.

\footnotetext{
${ }^{11}$ Breen, Hodrick, and Korajczyk (2002) develop a similar measure of equity price impact and find a positive relation between order flow and price change in the equity market as well.
} 


\section{Conclusions and future work}

Using a unique data set of foreign-exchange customer transactions, I find that the number of sizes traded increases significantly at quarter-ends. This evidence suggests that the quantity dimension is more binding at quarter-end, perhaps because of a heightened desire to have portfolios fully aligned with their stated objectives at times of greater scrutiny. Insignificant changes in the number of trades, total volume, and distribution of trade sizes, together with trading patterns in currency futures, all suggest that it is customers' increasing desire to satisfy their quantity demands, rather than a change in those exogenous demands or order-splitting, that drives the increase in quantities traded at quarter-end. At quarter-end customers trade more odd sizes and fewer round sizes. I also find that when customers care more about getting their desired quantity, they suffer a greater price impact to trade.

This work highlights the need to consider all three dimensions, quantity, time, and price, in evaluating liquidity. The price impact results suggest that the extent to which the quantity dimension binds may explain some of the time-series and cross-sectional variations in common liquidity measures. Future work will examine how investors trade off all three dimensions by comparing orders to executions and explore the links between these trade-offs and common liquidity measures.

This work also offers an explanation for the clustering of trade sizes. The existence of this effect across many customer types, not only those unique to the foreign-exchange market, suggests that it may occur in other asset markets as well. Although it is difficult to determine true trade size from most equity transaction data sets, Alexander and Peterson (2004) document tradesize clustering in NYSE stocks and find that the clustering centers on multiples of a few round sizes. In the fixed income market, researchers have observed trade-size as well as price clustering 
in transaction data sets, but to my knowledge a formal analysis has yet to be undertaken. Future work will examine how trade-size clustering is manifested in these other markets and how it relates to price clustering. Many empirical questions remain, including whether trade-size clustering and price clustering are substitutes or complements. 


\section{References}

Admati, A., Pfleiderer, P., 1988. A theory of intraday patterns: Volume and price variability. Review of Financial Studies 1, 3-40.

Alexander, G., Peterson, M., 2004. An analysis of trade-size clustering and its relationship to stealth trading. Unpublished working paper. University of Minnesota.

Bank for International Settlements, 2002. BIS Triennial Central Bank Survey: Foreign exchange and derivatives market activity in 2001.

Barclay, M., Warner, J., 1993. Stealth trading and volatility: Which trades move prices? Journal of Financial Economics 34, 281-305.

Black, F., 1971. Towards a fully automated exchange, part I. Financial Analysts Journal 27, 29$35,44$.

Bessembinder, H., 1994. Bid-ask spreads in the interbank foreign exchange markets. Journal of Financial Economics 35, 317-348.

Breen, W., Hodrick, L.S., Korajczyk, R., 2002. Predicting equity liquidity. Management Science 48, 470-483.

Brennan, M., Subrahmanyam, A., 1998. The determinants of average trade size. Journal of Business 71, 1-25.

Brown, S., Steenbeek, O., 2001. Doubling: Nick Leeson's trading strategy. Pacific-Basin Finance Journal 9, 83-99.

Chan, K., Fong, W., 2000. Trade size, order imbalance, and the volatility-volume relation. Journal of Financial Economics 57, 247-273.

Chordia, T., Roll, R., Subrahmanyam, A., 2000. Commonality in liquidity, Journal of Financial Economics 56, 3-28.

Christie, W., Schultz, P., 1994. Why do Nasdaq market makers avoid odd-eighth quotes? Journal of Finance 49, 1813-1840.

Conrad, J., Hameed A., Niden, C., 1994. Volume and autocovariances in short-horizon individual security returns. Journal of Finance 49, 1305-1329. 
Copeland, T. Galai, D., 1983. Informational effects on the bid ask spread. Journal of Finance 38, 1457-1469.

Dominguez, K., 1998. Central bank intervention and exchange rate volatility. Journal of International Money and Finance 18, 161-190.

Downey, J., 2002. Foreign exchange: dollar gains on yen, is flat with euro with scant reaction to Fed rate view. Wall Street Journal, March 20, 2002, C15.

Easley, D., O’Hara, M., 1987. Price, trade size and information in securities markets. Journal of Financial Economics 19, 69-90.

Evans, M., Lyons, R., 2002. Order flow and exchange rate dynamics. Journal of Political Economy 110, 170-180.

Fan, M., Lyons, R., 2003. Customer trades and extreme events in foreign exchange. In: Mizen, P. (Ed.), Monetary History, Exchange Rates and Financial Markets: Essays in Honour of Charles Goodhart. Edward Elgar, Northampton, MA, pp. 160-179.

Foster, F.D., Viswanathan, S., 1990. A theory of interday variations in volume, variance, and trading costs in securities markets. Review of Financial Studies 3, 593-624.

Glosten, L., Harris, L., 1988. Estimating the components of the bid-ask spread. Journal of Financial Economics 21, 123-142.

Glosten, L, Milgrom, P., 1985. Bid, ask and transaction prices in a specialist market with heterogeneously informed traders. Journal of Financial Economics 14, 71-100.

Grossman, S., Miller, M., Cone, K., Fischel, D., Ross, D., 1997. Clustering and competition in asset markets. Journal of Law and Economics 40, 23-60.

Hodrick, L.S., Moulton, P., 2003. Liquidity. Unpublished working paper. Columbia Business School.

Jones, C., Kaul, G., Lipson, M., 1994. Transactions, volume, and volatility. Review of Financial Studies 7, 631-651.

Kandel, S., Sarig, O., Wohl, A., 2001. Do investors prefer round stock prices? Evidence from Israeli IPO auctions. Journal of Banking and Finance 25, 1543-1551. 
Kavajecz, K., Odders-White, E., 2004. Technical analysis and liquidity provision, Review of Financial Studies 17, 1043-1071.

Kyle, A., 1985. Continuous auctions and insider trading. Econometrica 53, 1315-1335.

Lyons, R., 1995. Tests of microstructural hypotheses in the foreign exchange market. Journal of Financial Economics 39, 321-351.

McInish, T., Wood, R., 1991. Hourly returns, volume, trade size, and number of trades. Journal of Financial Research 14, 303-315.

Mitchell, J., 2001. Clustering and psychological barriers: The importance of numbers. Journal of Futures Markets 21, 395-428.

Osler, C., 2003. Currency orders and exchange rate dynamics: An explanation for the predictive success of technical analysis. Journal of Finance 58, 1791-1819.

Reuters, 2003. History of central bank intervention. January 31, Reuters.

Spiegel, M., Subrahmanyam, A., 1992. Informed speculation and hedging in a noncompetitive securities market. Review of Financial Studies 5, 307-329.

Yao, J., 1997. Market making in the interbank foreign exchange market. Unpublished working paper. New York University.

Yule, G.U., 1927. On reading a scale. Journal of the Royal Statistical Society 90, 570-587. 


\section{Table 1}

\section{Summary Statistics for Foreign-Exchange Transaction Data}

This table displays descriptive statistics for the bank's customer transactions in the six major currency pairs, euro (EUR), Japanese yen (JPY), British pound (GBP), Australian dollar (AUD), Swiss franc (CHF), and Canadian dollar (CAD), all versus the U.S. dollar. Period covered is January 3, 2000 to December 31, 2002. Number of trading days varies by currency because of national holidays.

\begin{tabular}{|c|c|c|c|c|c|c|}
\hline & EUR & JPY & GBP & AUD & CHF & CAD \\
\hline \multicolumn{7}{|l|}{ Daily Trades } \\
\hline Mean & 702 & 500 & 340 & 161 & 159 & 83 \\
\hline Std. Dev. & 245 & 173 & 111 & 67 & 63 & 38 \\
\hline $25 \%$ & 486 & 362 & 248 & 105 & 112 & 55 \\
\hline $75 \%$ & 865 & 601 & 423 & 207 & 194 & 104 \\
\hline \multicolumn{7}{|l|}{ Daily Sizes } \\
\hline Mean & 351 & 228 & 213 & 81 & 75 & 49 \\
\hline Std. Dev. & 107 & 65 & 65 & 27 & 30 & 20 \\
\hline $25 \%$ & 277 & 184 & 173 & 62 & 56 & 36 \\
\hline $75 \%$ & 407 & 266 & 246 & 96 & 87 & 57 \\
\hline \multicolumn{7}{|c|}{ Daily Volume (\$mn) } \\
\hline Mean & 5,030 & 3,594 & 1,910 & 781 & 910 & 412 \\
\hline Std. Dev. & 2,856 & 1,422 & 924 & 563 & 562 & 366 \\
\hline $25 \%$ & 3,478 & 2,645 & 1,271 & 410 & 542 & 173 \\
\hline $75 \%$ & 5,821 & 4,429 & 2,319 & 1,006 & 1,164 & 500 \\
\hline \multicolumn{7}{|c|}{ Average Daily Trade Size (\$mn) } \\
\hline Mean & 7.487 & 7.399 & 5.958 & 5.286 & 5.923 & 5.412 \\
\hline Std. Dev. & 3.865 & 2.551 & 3.125 & 4.348 & 3.408 & 5.946 \\
\hline $25 \%$ & 5.383 & 5.635 & 3.872 & 2.721 & 3.753 & 2.383 \\
\hline $75 \%$ & 8.733 & 8.651 & 7.226 & 6.384 & 7.079 & 6.211 \\
\hline \multicolumn{7}{|l|}{ Sample Totals } \\
\hline Days & 769 & 761 & 770 & 772 & 768 & 771 \\
\hline Trades & 539,629 & 380,184 & 261,424 & 124,470 & 122,104 & 63,711 \\
\hline Volume (\$bn) & 3,868 & 2,735 & 1,470 & 603 & 699 & 317 \\
\hline
\end{tabular}




\section{Table 2}

\section{End-of-Quarter Impact on Number of Sizes: Basic and Extended Specifications}

This table reports the coefficient estimates, with t-statistics in parentheses, of the following regression equations for each of the six major currencies. Newey-West standard errors are computed using five lags.

Panel A: Sizes $_{\mathrm{t}}=\alpha+\beta_{1} \mathrm{EOQ}_{\mathrm{t}}+\beta_{2} \operatorname{Trades}_{\mathrm{t}}+\varepsilon_{\mathrm{t}}$

Panel B: $\quad$ Sizes $_{t}=\alpha+\beta_{1}$ EOQ $_{t}+\beta_{2}$ Trades $_{t}+\beta_{3}$ NonEOQ $_{t}+\beta_{4}$ PriceLevel $_{t}+\beta_{5}$ ImpVol $_{t}+\beta_{6}$ Period9/11 $_{t}$

$$
+\beta_{7} \text { FutExp }_{\mathrm{t}}+\beta_{8} \mathrm{CBI}_{\mathrm{t}}+\varepsilon_{\mathrm{t}}
$$

Sizes $_{\mathrm{t}}$ is the number of distinct quantities traded on day $\mathrm{t}$. EOQ $\mathrm{t}$ is an indicator taking the value 1 if day $\mathrm{t}$ is in the last two weeks of a calendar quarter, else 0 . Trades $t$ is the number of transactions on day $t$. NonEOQ $\mathrm{Q}_{t}$ is an indicator taking the value 1 if day $t$ is in the last two weeks of a calendar month that is not the end of a calendar quarter, else 0 . PriceLevel is an indicator taking the value 1 if the currency crossed a major price level on day t, else 0 . ImpVol is the implied volatility for one-month currency options on day $t$. Period $9 / 11_{t}$ is an indicator taking the value 1 if day $\mathrm{t}$ is in the period 9/11/01 to 9/14/01, else 0. FutExp $\mathrm{t}$ is an indicator taking the value 1 if the related futures contract expired on day $\mathrm{t}$, else $0 . \mathrm{CBI}_{\mathrm{t}}$ is an indicator taking the value 1 if there was central bank intervention on day $\mathrm{t}$, else 0 . Period covered is January 3, 2000 to December 31, 2002. Number of observations varies by currency because of national holidays.

\begin{tabular}{|c|c|c|c|c|c|c|}
\hline & EUR & JPY & GBP & AUD & CHF & CAD \\
\hline \multicolumn{7}{|c|}{ Panel A: Basic Specification } \\
\hline Constant & $\begin{array}{c}73.46^{\mathrm{a}} \\
(10.16)\end{array}$ & $\begin{array}{c}63.13^{\mathrm{a}} \\
(12.70)\end{array}$ & $\begin{array}{l}33.42^{\mathrm{a}} \\
(6.06)\end{array}$ & $\begin{array}{l}22.64^{\mathrm{a}} \\
(13.88)\end{array}$ & $\begin{array}{l}7.60^{\mathrm{a}} \\
(4.61)\end{array}$ & $\begin{array}{l}7.87^{\mathrm{a}} \\
(7.60)\end{array}$ \\
\hline End-of-Quarter & $\begin{array}{l}13.00^{\mathrm{b}} \\
(1.98)\end{array}$ & $\begin{array}{l}10.35^{\mathrm{a}} \\
(2.64)\end{array}$ & $\begin{array}{l}14.22^{\mathrm{a}} \\
(3.23)\end{array}$ & $\begin{array}{c}2.61^{\mathrm{c}} \\
(1.76)\end{array}$ & $\begin{array}{l}3.59^{\mathrm{a}} \\
(2.62)\end{array}$ & $\begin{array}{l}1.97^{\mathrm{a}} \\
(2.62)\end{array}$ \\
\hline Trades & $\begin{array}{c}0.39^{\mathrm{a}} \\
(34.74)\end{array}$ & $\begin{array}{c}0.33^{\mathrm{a}} \\
(31.00)\end{array}$ & $\begin{array}{c}0.52^{\mathrm{a}} \\
(34.88)\end{array}$ & $\begin{array}{c}0.36^{\mathrm{a}} \\
(33.46)\end{array}$ & $\begin{array}{c}0.42^{\mathrm{a}} \\
(34.96)\end{array}$ & $\begin{array}{c}0.49^{\mathrm{a}} \\
(35.90)\end{array}$ \\
\hline \multicolumn{7}{|c|}{ Panel B: Extended Specification } \\
\hline Constant & $\begin{array}{l}52.25^{\mathrm{a}} \\
(3.40)\end{array}$ & $\begin{array}{l}44.07^{\mathrm{a}} \\
(3.72)\end{array}$ & $\begin{array}{l}26.72^{\mathrm{b}} \\
(2.46)\end{array}$ & $\begin{array}{l}31.16^{\mathrm{a}} \\
(7.90)\end{array}$ & $\begin{array}{c}1.60 \\
(0.30)\end{array}$ & $\begin{array}{l}12.56^{\mathrm{a}} \\
(3.18)\end{array}$ \\
\hline End-of-Quarter & $\begin{array}{l}12.34^{\mathrm{c}} \\
(1.81)\end{array}$ & $\begin{array}{l}11.55^{\mathrm{a}} \\
(2.62)\end{array}$ & $\begin{array}{l}12.43^{\mathrm{a}} \\
(2.64)\end{array}$ & $\begin{array}{l}4.53^{\mathrm{a}} \\
(2.88)\end{array}$ & $\begin{array}{l}3.10^{\mathrm{b}} \\
(2.03)\end{array}$ & $\begin{array}{l}2.19^{\mathrm{a}} \\
(2.73)\end{array}$ \\
\hline Trades & $\begin{array}{c}0.40^{\mathrm{a}} \\
(33.16)\end{array}$ & $\begin{array}{c}0.33^{\mathrm{a}} \\
(28.90)\end{array}$ & $\begin{array}{c}0.53^{\mathrm{a}} \\
(33.55)\end{array}$ & $\begin{array}{c}0.35^{\mathrm{a}} \\
(33.55)\end{array}$ & $\begin{array}{c}0.43^{\mathrm{a}} \\
(32.40)\end{array}$ & $\begin{array}{c}0.49^{\mathrm{a}} \\
(34.13)\end{array}$ \\
\hline $\begin{array}{l}\text { Non-EOQ } \\
\text { End-of-Month }\end{array}$ & $\begin{array}{c}2.39 \\
(0.50)\end{array}$ & $\begin{array}{c}2.95 \\
(1.05)\end{array}$ & $\begin{array}{l}-5.64^{\mathrm{c}} \\
(-1.65)\end{array}$ & $\begin{array}{c}2.24 \\
(1.75)\end{array}$ & $\begin{array}{l}-1.08 \\
(-0.99)\end{array}$ & $\begin{array}{c}1.05 \\
(1.53)\end{array}$ \\
\hline PriceLevel & $\begin{array}{l}-7.71^{\mathrm{c}} \\
(-1.82)\end{array}$ & $\begin{array}{l}-5.58^{\mathrm{c}} \\
(-1.92)\end{array}$ & $\begin{array}{c}-0.66 \\
(-0.20)\end{array}$ & $\begin{array}{c}1.12 \\
(1.21)\end{array}$ & $\begin{array}{l}-1.15 \\
(-0.28)\end{array}$ & $\begin{array}{c}0.02 \\
(0.03)\end{array}$ \\
\hline Implied Volatility & $\begin{array}{l}1.93^{\mathrm{c}} \\
(1.90)\end{array}$ & $\begin{array}{l}1.97^{\mathrm{b}} \\
(2.15)\end{array}$ & $\begin{array}{c}0.98 \\
(0.96)\end{array}$ & $\begin{array}{l}-0.78^{\mathrm{a}} \\
(-2.99)\end{array}$ & $\begin{array}{l}0.58^{\mathrm{b}} \\
(2.12)\end{array}$ & $\begin{array}{c}-0.83 \\
(-1.17)\end{array}$ \\
\hline 9/11 Period & $\begin{array}{l}-19.59 \\
(-1.09)\end{array}$ & $\begin{array}{l}-15.82^{\mathrm{c}} \\
(-1.88)\end{array}$ & $\begin{array}{l}12.95 \\
(1.06)\end{array}$ & $\begin{array}{l}-13.56^{\mathrm{a}} \\
(-6.84)\end{array}$ & $\begin{array}{l}-9.96^{\mathrm{a}} \\
(-6.04)\end{array}$ & $\begin{array}{l}-5.23^{\mathrm{a}} \\
(-6.07)\end{array}$ \\
\hline Futures Expiration & $\begin{array}{l}10.23 \\
(1.03)\end{array}$ & $\begin{array}{l}-14.63 \\
(-1.62)\end{array}$ & $\begin{array}{c}-3.07 \\
(-0.51)\end{array}$ & $\begin{array}{l}-11.69^{a} \\
(-2.66)\end{array}$ & $\begin{array}{c}3.18 \\
(0.50)\end{array}$ & $\begin{array}{c}3.64 \\
(1.50)\end{array}$ \\
\hline $\begin{array}{l}\text { Central Bank } \\
\text { Intervention }\end{array}$ & $\begin{array}{c}-8.09 \\
(-0.57)\end{array}$ & $\begin{array}{l}-13.17 \\
(-1.62)\end{array}$ & $\begin{array}{c}-4.60 \\
(-0.49)\end{array}$ & $\begin{array}{c}-1.69 \\
(-0.73)\end{array}$ & $\begin{array}{c}-5.16 \\
(-1.60)\end{array}$ & $\begin{array}{l}-1.48 \\
(-0.96)\end{array}$ \\
\hline Number of Obs & 769 & 761 & 770 & 772 & 768 & 771 \\
\hline
\end{tabular}

${ }^{\mathrm{a}}$ significant at $1 \%,{ }^{\mathrm{b}}$ significant at $5 \%,{ }^{\mathrm{c}}$ significant at $10 \%$ 


\section{Table 3}

\section{End-of-Quarter Impact on Number of Sizes: By Customer Year-End}

This table reports the coefficient estimates, with t-statistics in parentheses, of the following regression equations for each of the six major currencies. NeweyWest standard errors are computed using five lags.

Panel A: $\quad$ Sizes $_{\mathrm{t}}=\alpha+\beta_{1} \mathrm{EOQ}_{\mathrm{t}}+\beta_{2}$ Trades $_{\mathrm{t}}+\varepsilon_{\mathrm{t}}$

Panel B: $\quad$ Sizes $_{\mathrm{t}}=\alpha+\beta_{1}$ NonEOYEOQ $_{\mathrm{t}}+\beta_{2} \mathrm{EOY}_{\mathrm{t}}+\beta_{3}$ Trades $_{\mathrm{t}}+\varepsilon_{\mathrm{t}}$

Sizes $_{t}$ is the number of distinct quantities traded on day $t$. EOQ $\mathrm{E}_{\mathrm{t}}$ is an indicator taking the value 1 if day $\mathrm{t}$ is in the last two weeks of a calendar quarter, else 0 . Trades $_{t}$ is the number of transactions on day $t$. NonEOYEOQ ${ }_{t}$ is an indicator taking the value 1 if day $t$ is in the last two weeks of a fiscal quarter other than the fiscal year-end of interest, else 0. EOY $_{t}$ is an indicator taking the value 1 if day $t$ is in the last two weeks of the fiscal year of interest, else 0 . Period covered is January 3, 2000 to December 31, 2002. Number of observations varies by currency because of national holidays and customer activity. Only one currency is analyzed for March and June year-ends because trading in the other currencies by customers with those fiscal year-ends is minimal.

\begin{tabular}{|c|c|c|c|c|c|c|c|c|}
\hline Year-End & Dec & Dec & Dec & Dec & Dec & Dec & Mar & Jun \\
\hline Currency & EUR & JPY & GBP & AUD & CHF & CAD & JPY & AUD \\
\hline \multicolumn{9}{|c|}{ Panel A: End-of-Quarter } \\
\hline Constant & $\begin{array}{l}38.37^{\mathrm{a}} \\
(5.95)\end{array}$ & $\begin{array}{l}41.98^{\mathrm{a}} \\
(11.30)\end{array}$ & $\begin{array}{l}14.58^{\mathrm{a}} \\
(3.13)\end{array}$ & $\begin{array}{l}7.59^{\mathrm{a}} \\
(7.07)\end{array}$ & $\begin{array}{l}5.02^{\mathrm{a}} \\
(3.16)\end{array}$ & $\begin{array}{l}5.47^{\mathrm{a}} \\
(8.72)\end{array}$ & $\begin{array}{l}9.02^{\mathrm{a}} \\
(6.89)\end{array}$ & $\begin{array}{c}7.19^{\mathrm{a}} \\
(16.27)\end{array}$ \\
\hline End-of-Quarter & $\begin{array}{c}9.66 \\
(1.52)\end{array}$ & $\begin{array}{c}4.37 \\
(1.26)\end{array}$ & $\begin{array}{l}11.91^{\mathrm{a}} \\
(2.69)\end{array}$ & $\begin{array}{l}1.90^{\mathrm{b}} \\
(1.98)\end{array}$ & $\begin{array}{l}3.45^{\mathrm{b}} \\
(2.21)\end{array}$ & $\begin{array}{c}0.96 \\
(1.43)\end{array}$ & $\begin{array}{l}4.06^{\mathrm{a}} \\
(3.13)\end{array}$ & $\begin{array}{l}1.40^{\mathrm{b}} \\
(2.12)\end{array}$ \\
\hline Trades & $\begin{array}{c}0.52^{\mathrm{a}} \\
(35.47)\end{array}$ & $\begin{array}{c}0.42^{\mathrm{a}} \\
(33.25)\end{array}$ & $\begin{array}{c}0.68^{\mathrm{a}} \\
(32.73)\end{array}$ & $\begin{array}{c}0.60^{\mathrm{a}} \\
(50.35)\end{array}$ & $\begin{array}{c}0.50^{\mathrm{a}} \\
(30.85)\end{array}$ & $\begin{array}{c}0.63^{\mathrm{a}} \\
(48.92)\end{array}$ & $\begin{array}{c}0.49^{\mathrm{a}} \\
(25.32)\end{array}$ & $\begin{array}{c}0.22^{\mathrm{a}} \\
(11.90)\end{array}$ \\
\hline \multicolumn{9}{|c|}{ Panel B: End-of-Quarter and End-of-Year } \\
\hline Constant & $\begin{array}{l}38.08^{\mathrm{a}} \\
(5.95)\end{array}$ & $\begin{array}{c}42.27^{\mathrm{a}} \\
(11.70)\end{array}$ & $\begin{array}{l}14.76^{\mathrm{a}} \\
(3.19)\end{array}$ & $\begin{array}{l}7.60^{\mathrm{a}} \\
(7.07)\end{array}$ & $\begin{array}{l}5.09^{\mathrm{a}} \\
(3.21)\end{array}$ & $\begin{array}{l}5.46^{\mathrm{a}} \\
(8.73)\end{array}$ & $\begin{array}{l}8.93^{\mathrm{a}} \\
(6.77)\end{array}$ & $\begin{array}{c}7.19^{\mathrm{a}} \\
(16.29)\end{array}$ \\
\hline $\begin{array}{l}\text { Non-End-of-Year } \\
\text { End-of-Quarter }\end{array}$ & $\begin{array}{l}13.71^{\mathrm{c}} \\
(1.92)\end{array}$ & $\begin{array}{l}7.89^{\mathrm{b}} \\
(2.16)\end{array}$ & $\begin{array}{l}15.69^{\mathrm{a}} \\
(3.48)\end{array}$ & $\begin{array}{l}2.05^{\mathrm{c}} \\
(1.80)\end{array}$ & $\begin{array}{l}4.46^{\mathrm{a}} \\
(2.71)\end{array}$ & $\begin{array}{c}1.15 \\
(1.55)\end{array}$ & $\begin{array}{l}5.66^{\mathrm{a}} \\
(3.87)\end{array}$ & $\begin{array}{l}1.24^{\mathrm{c}} \\
(1.81)\end{array}$ \\
\hline End-of-Year & $\begin{array}{c}-5.01 \\
(-0.48)\end{array}$ & $\begin{array}{l}9.22^{\mathrm{c}} \\
(1.95)\end{array}$ & $\begin{array}{c}-1.69 \\
(-0.18)\end{array}$ & $\begin{array}{c}1.37 \\
(1.17)\end{array}$ & $\begin{array}{c}0.02 \\
(0.01)\end{array}$ & $\begin{array}{c}0.30 \\
(0.22)\end{array}$ & $\begin{array}{c}-0.65 \\
(-0.41)\end{array}$ & $\begin{array}{c}1.85 \\
(1.26)\end{array}$ \\
\hline Trades & $\begin{array}{c}0.52^{\mathrm{a}} \\
(35.72)\end{array}$ & $\begin{array}{c}0.42^{\mathrm{a}} \\
(33.97)\end{array}$ & $\begin{array}{c}0.68^{\mathrm{a}} \\
(32.78)\end{array}$ & $\begin{array}{c}0.60^{\mathrm{a}} \\
(50.37)\end{array}$ & $\begin{array}{c}0.50^{\mathrm{a}} \\
(30.82)\end{array}$ & $\begin{array}{c}0.63^{\mathrm{a}} \\
(49.01)\end{array}$ & $\begin{array}{c}0.49^{\mathrm{a}} \\
(25.18)\end{array}$ & $\begin{array}{c}0.22^{\mathrm{a}} \\
(11.89)\end{array}$ \\
\hline Number of Obs & 769 & 761 & 770 & 772 & 768 & 771 & 746 & 768 \\
\hline
\end{tabular}

${ }^{\mathrm{a}}$ significant at $1 \%,{ }^{\mathrm{b}}$ significant at $5 \%,{ }^{\mathrm{c}}$ significant at $10 \%$ 


\section{Table 4}

\section{End-of-Quarter Impact on Number of Sizes: Customer Types}

This table reports the coefficient estimates, with t-statistics in parentheses, of the following regression equation for each of the six major currencies by customer type. Newey-West standard errors are computed using five lags.

Sizes $_{\mathrm{t}}=\alpha+\beta_{1} \mathrm{EOQ}_{\mathrm{t}}+\beta_{2}$ Trades $_{\mathrm{t}}+\varepsilon_{\mathrm{t}}$

Sizes $_{\mathrm{t}}$ is the number of distinct quantities traded on day $\mathrm{t}$ by the specified customer type. EOQ $\mathrm{Q}_{\mathrm{t}}$ is an indicator taking the value 1 if day $t$ is in the last two weeks of a calendar quarter, else 0 . Trades ${ }_{t}$ is the number of transactions on day $\mathrm{t}$ by the specified customer type. For brevity, constants are not reported in the table. Period covered is January 3 , 2000 to December 31, 2002. Number of observations varies by currency because of national holidays.

\begin{tabular}{|c|c|c|c|c|c|c|}
\hline & EUR & JPY & GBP & AUD & $\mathrm{CHF}$ & CAD \\
\hline \multicolumn{7}{|c|}{ Panel A: Corporate Hedgers } \\
\hline End-of-Quarter & $\begin{array}{l}1.15^{\mathrm{c}} \\
(1.89)\end{array}$ & $\begin{array}{c}0.27^{\mathrm{b}} \\
(2.06)\end{array}$ & $\begin{array}{c}1.47^{\mathrm{a}} \\
(3.02)\end{array}$ & $\begin{array}{c}0.21^{\mathrm{c}} \\
(1.80)\end{array}$ & $\begin{array}{l}0.25^{\mathrm{a}} \\
(2.76)\end{array}$ & $\begin{array}{l}0.11^{\mathrm{b}} \\
(2.09)\end{array}$ \\
\hline Trades & $\begin{array}{c}0.39^{\mathrm{a}} \\
(36.21)\end{array}$ & $\begin{array}{c}0.36^{\mathrm{a}} \\
(32.36)\end{array}$ & $\begin{array}{c}0.52^{\mathrm{a}} \\
(34.88)\end{array}$ & $\begin{array}{c}0.37^{\mathrm{a}} \\
(33.33)\end{array}$ & $\begin{array}{c}0.43^{\mathrm{a}} \\
(41.15)\end{array}$ & $\begin{array}{c}0.48^{\mathrm{a}} \\
(40.52)\end{array}$ \\
\hline \multicolumn{7}{|c|}{ Panel B: Mutual Funds } \\
\hline End-of-Quarter & $\begin{array}{l}3.80^{\mathrm{c}} \\
(1.96)\end{array}$ & $\begin{array}{l}2.63^{\mathrm{a}} \\
(2.62)\end{array}$ & $\begin{array}{c}3.88^{\mathrm{a}} \\
(3.19)\end{array}$ & $\begin{array}{l}0.84^{\mathrm{c}} \\
(1.74)\end{array}$ & $\begin{array}{l}1.42^{\mathrm{a}} \\
(2.66)\end{array}$ & $\begin{array}{l}0.93^{\mathrm{a}} \\
(2.65)\end{array}$ \\
\hline Trades & $\begin{array}{c}0.39^{\mathrm{a}} \\
(34.09)\end{array}$ & $\begin{array}{c}0.33^{\mathrm{a}} \\
(31.49)\end{array}$ & $\begin{array}{c}0.53^{\mathrm{a}} \\
(35.28)\end{array}$ & $\begin{array}{c}0.36^{\mathrm{a}} \\
(33.27)\end{array}$ & $\begin{array}{c}0.42^{\mathrm{a}} \\
(34.72)\end{array}$ & $\begin{array}{c}0.49^{\mathrm{a}} \\
(35.84)\end{array}$ \\
\hline \multicolumn{7}{|c|}{ Panel C: CTAs } \\
\hline End-of-Quarter & $\begin{array}{l}1.09^{\mathrm{b}} \\
(2.10)\end{array}$ & $\begin{array}{l}0.62^{\mathrm{b}} \\
(2.36)\end{array}$ & $\begin{array}{l}1.08^{\mathrm{a}} \\
(3.29)\end{array}$ & $\begin{array}{c}0.22^{\mathrm{c}} \\
(1.80)\end{array}$ & $\begin{array}{l}0.36^{\mathrm{b}} \\
(2.36)\end{array}$ & $\begin{array}{l}0.15^{\mathrm{b}} \\
(2.47)\end{array}$ \\
\hline Trades & $\begin{array}{c}0.40^{\mathrm{a}} \\
(38.94)\end{array}$ & $\begin{array}{c}0.34^{\mathrm{a}} \\
(34.74)\end{array}$ & $\begin{array}{c}0.53^{\mathrm{a}} \\
(38.33)\end{array}$ & $\begin{array}{c}0.37^{\mathrm{a}} \\
(32.64)\end{array}$ & $\begin{array}{c}0.42^{\mathrm{a}} \\
(35.67)\end{array}$ & $\begin{array}{c}0.49^{\mathrm{a}} \\
(37.36)\end{array}$ \\
\hline \multicolumn{7}{|c|}{ Panel D: Hedge Funds } \\
\hline End-of-Quarter & $\begin{array}{l}2.39^{\mathrm{c}} \\
(1.96)\end{array}$ & $\begin{array}{l}3.66^{\mathrm{a}} \\
(2.70)\end{array}$ & $\begin{array}{c}2.16^{\mathrm{a}} \\
(3.23)\end{array}$ & $\begin{array}{c}0.48 \\
(1.49)\end{array}$ & $\begin{array}{l}0.74^{\mathrm{a}} \\
(2.88)\end{array}$ & $\begin{array}{l}0.19^{\mathrm{b}} \\
(2.47)\end{array}$ \\
\hline Trades & $\begin{array}{c}0.39^{\mathrm{a}} \\
(34.72)\end{array}$ & $\begin{array}{c}0.33^{\mathrm{a}} \\
(30.84)\end{array}$ & $\begin{array}{c}0.53^{\mathrm{a}} \\
(36.10)\end{array}$ & $\begin{array}{c}0.36^{\mathrm{a}} \\
(32.64)\end{array}$ & $\begin{array}{c}0.42^{\mathrm{a}} \\
(35.41)\end{array}$ & $\begin{array}{c}0.49^{\mathrm{a}} \\
(36.99)\end{array}$ \\
\hline \multicolumn{7}{|c|}{ Panel E: Relative Value Traders } \\
\hline End-of-Quarter & $\begin{array}{l}1.83^{\mathrm{c}} \\
(1.86)\end{array}$ & $\begin{array}{c}1.03^{\mathrm{b}} \\
(2.50)\end{array}$ & $\begin{array}{c}2.84^{\mathrm{a}} \\
(3.20)\end{array}$ & $\begin{array}{c}0.27^{\mathrm{c}} \\
(1.79)\end{array}$ & $\begin{array}{l}0.21^{\mathrm{b}} \\
(2.49)\end{array}$ & $\begin{array}{c}0.20^{\mathrm{c}} \\
(1.82)\end{array}$ \\
\hline Trades & $\begin{array}{c}0.39^{\mathrm{a}} \\
(35.64)\end{array}$ & $\begin{array}{c}0.33^{\mathrm{a}} \\
(31.97)\end{array}$ & $\begin{array}{c}0.52^{\mathrm{a}} \\
(35.49)\end{array}$ & $\begin{array}{c}0.35^{\mathrm{a}} \\
(32.83)\end{array}$ & $\begin{array}{c}0.41^{\mathrm{a}} \\
(35.24)\end{array}$ & $\begin{array}{c}0.49^{\mathrm{a}} \\
(36.44)\end{array}$ \\
\hline Number of Obs & 769 & 761 & 770 & 772 & 768 & 771 \\
\hline
\end{tabular}




\section{Table 5}

\section{End-of-Quarter Changes in Sizes and Trades}

This table reports the results of two-sided t-tests (with unequal variances) on the means of size and trade measures during end-of-quarter (EOQ) and non-end-of-quarter (Non-EOQ) periods. EOQ refers to all days falling in the last two weeks of a calendar quarter; Non-EOQ refers to all days not falling in the last two weeks of a calendar quarter. Sizes is the number of distinct quantities traded per day. Trades is the number of trades per day. Volume is the total volume in USD per day. Average Size is the average trade size in USD per day. Size Interquartile Range is the difference between the $75^{\text {th }}$ and the $25^{\text {th }}$ percentile trade size in USD per day. Period covered is January 3 , 2000 to December 31, 2002. Number of observations varies by currency because of national holidays.

\begin{tabular}{|c|c|c|c|c|c|c|}
\hline & Sizes & Trades & $\begin{array}{c}\text { Volume } \\
\text { (mn) }\end{array}$ & $\begin{array}{c}\text { Average } \\
\text { Size } \\
(000)\end{array}$ & $\begin{array}{c}\text { Size } \\
\text { Interquartile } \\
\text { Range } \\
(\mathbf{0 0 0})\end{array}$ & $\begin{array}{l}\text { Number of } \\
\text { Observations }\end{array}$ \\
\hline \multicolumn{7}{|l|}{ EUR } \\
\hline EOQ Average & 374 & 734 & 5,597 & 7,724 & 3,225 & 115 \\
\hline Non-EOQ Average & 347 & 696 & 4,931 & 7,445 & 3,171 & 654 \\
\hline p-value & .04 & .21 & .05 & .49 & .65 & \\
\hline \multicolumn{7}{|l|}{ JPY } \\
\hline EOQ Average & 239 & 507 & 3,750 & 7,693 & 4,385 & 112 \\
\hline Non-EOQ Average & 226 & 498 & 3,568 & 7,348 & 4,194 & 649 \\
\hline p-value & .05 & .62 & .27 & .30 & .33 & \\
\hline \multicolumn{7}{|l|}{ GBP } \\
\hline EOQ Average & 230 & 348 & 1,924 & 5,734 & 1,904 & 115 \\
\hline Non-EOQ Average & 210 & 338 & 1,907 & 5,997 & 2,071 & 655 \\
\hline $\mathrm{p}$-value & .01 & .41 & .85 & .33 & .10 & \\
\hline \multicolumn{7}{|l|}{ AUD } \\
\hline EOQ Average & 85 & 167 & 868 & 5,809 & 2,946 & 116 \\
\hline Non-EOQ Average & 80 & 160 & 766 & 5,193 & 2,513 & 656 \\
\hline p-value & .09 & .38 & .16 & .16 & .08 & \\
\hline \multicolumn{7}{|l|}{ CHF } \\
\hline EOQ Average & 79 & 161 & 997 & 6,381 & 4,533 & 115 \\
\hline Non-EOQ Average & 74 & 159 & 895 & 5,842 & 3,828 & 653 \\
\hline p-value & .10 & .67 & .09 & .15 & .03 & \\
\hline \multicolumn{7}{|l|}{ CAD } \\
\hline EOQ Average & 51 & 85 & 414 & 4,883 & 2,530 & 116 \\
\hline Non-EOQ Average & 48 & 82 & 411 & 5,506 & 2,954 & 655 \\
\hline p-value & .12 & .52 & .95 & .13 & .02 & \\
\hline
\end{tabular}




\section{Table 6}

\section{End-of-Quarter Impact on Number of Sizes: Round versus Odd Sizes}

This table reports the coefficient estimates, with t-statistics in parentheses, of the following regression equations for each of the six major currencies. Newey-West standard errors are computed using five lags.

Panel A: $\quad$ RoundSizes $_{t}=\alpha+\beta_{1}$ EOQ $_{t}+\beta_{2}$ Trades $_{t}+\varepsilon_{t}$

Panel B: OddSizes $_{t}=\alpha+\beta_{1}$ EOQ $_{t}+\beta_{2}$ Trades $_{t}+\varepsilon_{t}$

RoundSizes $_{\mathrm{t}}$ is the number of distinct round quantities, defined as round millions in either currency of the currency pair, traded on day $t$. $\mathrm{EOQ}_{\mathrm{t}}$ is an indicator taking the value 1 if day $\mathrm{t}$ is in the last two weeks of a calendar quarter, else 0 . Trades $s_{t}$ is the number of transactions on day t. OddSizes ${ }_{t}$ is the number of distinct odd quantities, defined as non-round millions in both currencies of the currency pair, traded on day t. Period covered is January 3, 2000 to December 31, 2002. Number of observations varies by currency because of national holidays.

\begin{tabular}{lcccccc}
\hline & EUR & JPY & GBP & AUD & CHF & CAD \\
\hline Constant & \multicolumn{7}{c}{ Panel A: Round Sizes } \\
& $16.00^{\mathrm{a}}$ & $18.34^{\mathrm{a}}$ & $8.19^{\mathrm{a}}$ & $7.45^{\mathrm{a}}$ & $4.81^{\mathrm{a}}$ & $2.88^{\mathrm{a}}$ \\
End-of-Quarter & $(26.79)$ & $(23.55)$ & $(16.26)$ & $(17.46)$ & $(13.26)$ & $(12.17)$ \\
& 0.95 & $2.71^{\mathrm{a}}$ & 0.20 & $0.93^{\mathrm{b}}$ & 0.33 & 0.29 \\
Trades & $(1.61)$ & $(3.98)$ & $(0.52)$ & $(2.12)$ & $(1.02)$ & $(0.85)$ \\
& $0.01^{\mathrm{a}}$ & $0.03^{\mathrm{a}}$ & $0.01^{\mathrm{a}}$ & $0.03^{\mathrm{a}}$ & $0.02^{\mathrm{a}}$ & $0.03^{\mathrm{a}}$ \\
& $(14.43)$ & $(21.56)$ & $(6.18)$ & $(11.29)$ & $(11.39)$ & $(10.12)$ \\
\hline Constant & \multicolumn{7}{c}{ Panel B: Odd Sizes } & & & \\
& $57.46^{\mathrm{a}}$ & $44.78^{\mathrm{a}}$ & $25.23^{\mathrm{a}}$ & $15.18^{\mathrm{a}}$ & 2.79 & $5.00^{\mathrm{a}}$ \\
End-of-Quarter & $(7.94)$ & $(8.77)$ & $(4.68)$ & $(9.24)$ & $(1.55)$ & $(4.66)$ \\
& $12.05^{\mathrm{c}}$ & $7.64^{\mathrm{b}}$ & $14.02^{\mathrm{a}}$ & 1.68 & $3.26^{\mathrm{b}}$ & $1.68^{\mathrm{c}}$ \\
Trades & $(1.83)$ & $(1.99)$ & $(3.28)$ & $(1.19)$ & $(2.15)$ & $(1.82)$ \\
& $0.38^{\mathrm{a}}$ & $0.29^{\mathrm{a}}$ & $0.52^{\mathrm{a}}$ & $0.33^{\mathrm{a}}$ & $0.40^{\mathrm{a}}$ & $0.46^{\mathrm{a}}$ \\
\hline Number of Obs & $(33.42)$ & $(27.07)$ & $(34.72)$ & $(29.95)$ & $(30.24)$ & $(32.37)$ \\
\hline
\end{tabular}

${ }^{\mathrm{a}}$ significant at $1 \%,{ }^{\mathrm{b}}$ significant at $5 \%,{ }^{\mathrm{c}}$ significant at $10 \%$ 


\section{Table 7}

\section{End-of-Quarter Changes in Round versus Odd Trades}

This table reports the results of one-sided t-tests (with unequal variances) on the means of the number of round trades and the number of odd trades during end-of-quarter (EOQ) and non-end-of-quarter (Non-EOQ) periods. EOQ refers to all days falling in the last two weeks of a calendar quarter; Non-EOQ refers to all days not falling in the last two weeks of a calendar quarter. Round Trades is the number of trades in round-quantity trades, defined as round millions on either side. Odd Trades is the number of non-round-quantity trades, defined as non-round millions on both sides. Period covered is January 3, 2000 to December 31, 2002. Number of observations varies by currency because of national holidays.

\begin{tabular}{|c|c|c|c|}
\hline & Round Trades & Odd Trades & Number of Observations \\
\hline \multicolumn{4}{|l|}{ EUR } \\
\hline EOQ Average & 169 & 564 & 115 \\
\hline Non-EOQ Average & 179 & 517 & 654 \\
\hline p-value & .09 & .02 & \\
\hline \multicolumn{4}{|l|}{ JPY } \\
\hline EOQ Average & 145 & 362 & 112 \\
\hline Non-EOQ Average & 158 & 340 & 649 \\
\hline p-value & .01 & .05 & \\
\hline \multicolumn{4}{|l|}{ GBP } \\
\hline EOQ Average & 37 & 310 & 115 \\
\hline Non-EOQ Average & 43 & 295 & 655 \\
\hline $\mathrm{p}$-value & .00 & .09 & \\
\hline \multicolumn{4}{|l|}{ AUD } \\
\hline EOQ Average & 34 & 133 & 116 \\
\hline Non-EOQ Average & 35 & 125 & 656 \\
\hline p-value & .14 & .11 & \\
\hline \multicolumn{4}{|l|}{ CHF } \\
\hline EOQ Average & 32 & 129 & 115 \\
\hline Non-EOQ Average & 35 & 123 & 653 \\
\hline p-value & .08 & .14 & \\
\hline \multicolumn{4}{|l|}{ CAD } \\
\hline EOQ Average & 10.6 & 74 & 116 \\
\hline Non-EOQ Average & 11.4 & 71 & 655 \\
\hline p-value & .10 & .17 & \\
\hline
\end{tabular}




\section{Table 8}

\section{End-of-Quarter Impact on Number of Futures Sizes}

This table reports the coefficient estimates, with t-statistics in parentheses, of the following regression equations for each of the six major currencies. Newey-West standard errors are computed using five lags.

Panel A: $\quad$ FutSizes $_{t}=\alpha+\beta_{1}$ EOQ $_{t}+\beta_{2}$ FutTrades $_{t}+\varepsilon_{t}$

Panel B: $\quad$ FutSizes $_{\mathrm{t}}=\alpha+\beta_{1}$ EOQ $_{\mathrm{t}}+\beta_{2}$ FutRoll $_{\mathrm{t}}+\beta_{3}$ FutTrades $_{\mathrm{t}}+\varepsilon_{\mathrm{t}}$

FutSizes $_{t}$ is the number of distinct futures quantities traded on day $t$. EOQ $\mathrm{E}_{\mathrm{t}}$ is an indicator taking the value 1 if day $\mathrm{t}$ is in the last two weeks of a calendar quarter, else 0. FutTrades $t_{t}$ is the number of futures transactions on day $t$. FutRoll $l_{t}$ is an indicator taking the value of 1 if day $t$ is in a two-week period ending on a futures expiration date, else 0. Period covered is January 3, 2000 to December 31, 2002.

\begin{tabular}{|c|c|c|c|c|c|c|}
\hline & EUR & JPY & GBP & AUD & CHF & CAD \\
\hline \multicolumn{7}{|c|}{ Panel A: End-of-Quarter } \\
\hline Constant & $\begin{array}{c}31.58^{\mathrm{a}} \\
(28.74)\end{array}$ & $\begin{array}{c}21.65^{\mathrm{a}} \\
(28.58)\end{array}$ & $\begin{array}{c}16.19^{\mathrm{a}} \\
(14.95)\end{array}$ & $\begin{array}{c}13.17^{\mathrm{a}} \\
(20.25)\end{array}$ & $\begin{array}{l}21.95^{\mathrm{a}} \\
(22.64)\end{array}$ & $\begin{array}{l}30.36^{\mathrm{a}} \\
(36.15)\end{array}$ \\
\hline End-of-Quarter & $\begin{array}{c}-0.88 \\
(-0.77)\end{array}$ & $\begin{array}{c}-0.61 \\
(-0.88)\end{array}$ & $\begin{array}{l}-1.86^{\mathrm{a}} \\
(-2.64)\end{array}$ & $\begin{array}{c}-0.89 \\
(-1.45)\end{array}$ & $\begin{array}{c}0.32 \\
(0.29)\end{array}$ & $\begin{array}{c}1.16 \\
(1.24)\end{array}$ \\
\hline Trades & $\begin{array}{c}0.00^{\mathrm{a}} \\
(18.66)\end{array}$ & $\begin{array}{c}0.01^{\mathrm{a}} \\
(29.52)\end{array}$ & $\begin{array}{c}0.01^{\mathrm{a}} \\
(19.72)\end{array}$ & $\begin{array}{c}0.01^{\mathrm{a}} \\
(11.13)\end{array}$ & $\begin{array}{c}0.01^{\mathrm{a}} \\
(16.16)\end{array}$ & $\begin{array}{c}0.00^{\mathrm{a}} \\
(18.14)\end{array}$ \\
\hline \multicolumn{7}{|c|}{ Panel B: End-of-Quarter and Futures Roll } \\
\hline Constant & $\begin{array}{c}31.60^{\mathrm{a}} \\
(28.60)\end{array}$ & $\begin{array}{c}21.66^{\mathrm{a}} \\
(28.60)\end{array}$ & $\begin{array}{c}16.19^{\mathrm{a}} \\
(14.93)\end{array}$ & $\begin{array}{c}13.15^{\mathrm{a}} \\
(19.89)\end{array}$ & $\begin{array}{l}21.93^{\mathrm{a}} \\
(22.23)\end{array}$ & $\begin{array}{l}30.43^{\mathrm{a}} \\
(35.08)\end{array}$ \\
\hline End-of-Quarter & $\begin{array}{c}-0.92 \\
(-0.80)\end{array}$ & $\begin{array}{c}-0.66 \\
(-0.93)\end{array}$ & $\begin{array}{l}-1.89^{a} \\
(-2.66)\end{array}$ & $\begin{array}{c}-0.81 \\
(-1.33)\end{array}$ & $\begin{array}{c}0.35 \\
(0.32)\end{array}$ & $\begin{array}{c}1.16 \\
(1.24)\end{array}$ \\
\hline Futures Roll & $\begin{array}{c}-0.39 \\
(-0.36)\end{array}$ & $\begin{array}{c}-0.51 \\
(-0.55)\end{array}$ & $\begin{array}{c}-0.22 \\
(-0.20)\end{array}$ & $\begin{array}{c}0.66 \\
(0.83)\end{array}$ & $\begin{array}{c}0.26 \\
(0.19)\end{array}$ & $\begin{array}{c}-0.58 \\
(-0.58)\end{array}$ \\
\hline Trades & $\begin{array}{c}0.00^{\mathrm{a}} \\
(18.70)\end{array}$ & $\begin{array}{c}0.01^{\mathrm{a}} \\
(29.87)\end{array}$ & $\begin{array}{c}0.01^{\mathrm{a}} \\
(20.37)\end{array}$ & $\begin{array}{c}0.01^{\mathrm{a}} \\
(11.03)\end{array}$ & $\begin{array}{c}0.01^{\mathrm{a}} \\
(16.78)\end{array}$ & $\begin{array}{c}0.00^{\mathrm{a}} \\
(18.53)\end{array}$ \\
\hline Number of Obs & 757 & 757 & 757 & 757 & 757 & 757 \\
\hline
\end{tabular}

${ }^{\mathrm{a}}$ significant at $1 \%,{ }^{\mathrm{b}}$ significant at $5 \%,{ }^{\mathrm{c}}$ significant at $10 \%$ 


\section{Table 9}

\section{End-of-Quarter Changes in Price, Order Flow, and Price Impact}

This table reports the results of two-sided t-tests (with unequal variances) on the means of price changes and net order flow and one-sided t-tests (with unequal variances) on the means of price impact during end-of-quarter (EOQ) and non-end-of-quarter (Non-EOQ) periods. EOQ refers to all days falling in the last two weeks of a calendar quarter; Non-EOQ refers to all days not falling in the last two weeks of a calendar quarter. Price Change is the percentage price change in a day. Absolute Price Change is the absolute value percentage price change in a day. Net order flow is the net customer trade flow (buy orders - sell orders) in USD millions per day. Price Impact is the percentage price change (not absolute value) divided by net order flow per day. Period covered is January 3 , 2000 to December 31, 2002. Number of observations varies by currency because of national holidays.

\begin{tabular}{|c|c|c|c|c|c|}
\hline & $\begin{array}{c}\text { Price } \\
\text { Change }\end{array}$ & $\begin{array}{c}\text { Absolute } \\
\text { Price } \\
\text { Change }\end{array}$ & $\begin{array}{c}\text { Net Order Flow } \\
(\mathbf{m n})\end{array}$ & $\begin{array}{c}\text { Price } \\
\text { Impact }\end{array}$ & $\begin{array}{c}\text { Number of } \\
\text { Observations }\end{array}$ \\
\hline \multicolumn{6}{|l|}{ EUR } \\
\hline EOQ Average & .00055 & .00502 & -21.249 & -.00000 & 115 \\
\hline Non-EOQ Average & .00009 & .00532 & -33.029 & -.00004 & 654 \\
\hline p-value & .49 & .49 & .88 & .18 & \\
\hline \multicolumn{6}{|l|}{ JPY } \\
\hline EOQ Average & .00018 & .00438 & -36.388 & .00013 & 112 \\
\hline Non-EOQ Average & .00015 & .00481 & -15.243 & .00001 & 649 \\
\hline p-value & .96 & .36 & .44 & .13 & \\
\hline \multicolumn{6}{|l|}{ GBP } \\
\hline EOQ Average & .00112 & .00348 & 45.610 & .00007 & 115 \\
\hline Non-EOQ Average & -.00014 & .00384 & -16.895 & -.00002 & 655 \\
\hline $\mathrm{p}$-value & .01 & .27 & .03 & .02 & \\
\hline \multicolumn{6}{|l|}{ AUD } \\
\hline EOQ Average & -.00091 & .00570 & 1.966 & .00080 & 116 \\
\hline Non-EOQ Average & -.00002 & .00542 & -17.392 & .00004 & 656 \\
\hline $\mathrm{p}$-value & .24 & .59 & .11 & .09 & \\
\hline \multicolumn{6}{|l|}{ CHF } \\
\hline EOQ Average & -.00010 & .00565 & 2.184 & .00065 & 115 \\
\hline Non-EOQ Average & -.00006 & .00530 & -6.822 & .00006 & 653 \\
\hline p-value & .21 & .44 & .35 & .00 & \\
\hline \multicolumn{6}{|l|}{ CAD } \\
\hline EOQ Average & .00021 & .00258 & 13.367 & .00022 & 116 \\
\hline Non-EOQ Average & .00008 & .00277 & 3.447 & .00002 & 655 \\
\hline p-value & .69 & .33 & .46 & .01 & \\
\hline
\end{tabular}




\section{Appendix}

\section{A.1. Non-linear specifications}

Table A1 displays the results from estimating two alternative specifications that consider non-linear relations between the number of sizes and number of trades in a day.

Panel A of Table A1 depicts a quadratic specification:

$$
\text { Sizes }_{t}=\alpha+\beta_{1} \text { EOQ }_{t}+\beta_{2} \text { Trades }_{t}+\beta_{3} \operatorname{TradesSq}_{t}+\varepsilon_{t}
$$

where TradesSq $\mathrm{q}_{\mathrm{t}}=$ total number of trades on day $\mathrm{t}$, squared

The coefficient estimates on the quarter-end indicator in Eq. (6) are similar in magnitude and significance to those obtained in the basic specification, displayed in Table 2. Although the squared trades term is statistically significant in five of the six currencies, it is not economically significant, with coefficient estimates very close to zero.

Panel B of Table A1 depicts the results from a log specification:

$$
\log \left(\text { Sizes }_{\mathrm{t}}\right)=\alpha+\beta_{1} \mathrm{EOQ}_{\mathrm{t}}+\beta_{2} \log \left(\text { Trades }_{\mathrm{t}}\right)+\varepsilon_{\mathrm{t}}
$$

where $\log \left(\right.$ Sizes $\left._{\mathrm{t}}\right)=$ natural logarithm of number of sizes traded on day $\mathrm{t}$

$$
\log \left(\text { Trades }_{\mathrm{t}}\right)=\text { natural logarithm of total number of trades on day } \mathrm{t}
$$

The coefficient estimates on the end-of-quarter indicator in Eq. (7) are positive and statistically significant. Overall, the results from estimating the effects of quarter-end on the number of sizes traded appear robust to non-linear specifications.

\section{A.2. Price impact regression analysis}

Table A2 examines the effect of quarter-end on price impact in a regression framework. In Panel A price impact is regressed on the quarter-end indicator and daily transaction volume:

$$
\begin{aligned}
\text { PriceImp }_{\mathrm{t}}=\alpha & +\beta_{1} \mathrm{EOQ}_{\mathrm{t}}+\beta_{2} \text { Volume }_{\mathrm{t}}+\varepsilon_{\mathrm{t}} \\
\text { where } & \text { PriceImp }_{\mathrm{t}}=\text { price impact on day } \mathrm{t} \\
& \mathrm{EOQ}=1 \text { if day } \mathrm{t} \text { is in end-of-quarter period, else } 0 \\
& \text { Volume }_{\mathrm{t}}=\text { transaction volume in USD billions on day } \mathrm{t}
\end{aligned}
$$


Daily transaction volume is included because prices may react to a given net order flow differently when it occurs on a high-volume versus a low-volume day. Quarter-end has a significantly positive effect on price impact for five of the six currencies. These results are robust to omission of the volume variable and replacement of volume with the number of trades; results available on request.

Panel B of Table A2 expands the analysis to include the additional explanatory variables from the extended specification of the size regression, Eq. (5), to see if some of the price impact effect can be traced directly to other factors driving the size results:

$$
\begin{aligned}
& \text { PriceImp }_{t}=\alpha+\beta_{1} \text { EOQ }_{t}+\beta_{2} \text { Volume }_{t}+\beta_{3} \text { NonEOQ }_{t}+\beta_{4} \text { PriceLeve }_{t}+\beta_{5} \operatorname{ImpVol}_{t}
\end{aligned}
$$

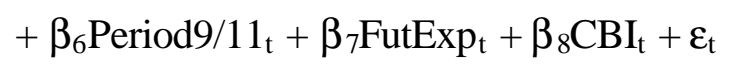

The significantly negative coefficient estimate on futures expiration in three currencies suggests that large net flows on futures expiration days move prices less than on other days, perhaps because they are viewed as less informative. Coefficients on the remaining additional explanatory variables are generally insignificant, while the quarter-end coefficients are little changed. 


\section{Table A1 \\ End-of-Quarter Impact on Number of Sizes: Non-Linear Specifications}

This table reports the coefficient estimates, with t-statistics in parentheses, of the following regression equations for each of the six major currencies. Newey-West standard errors are computed using five lags.

Panel A: $\quad$ Sizes $_{t}=\alpha+\beta_{1}$ EOQ $_{t}+\beta_{2}$ Trades $_{t}+\beta_{3} \operatorname{TradesSq}_{t}+\varepsilon_{t}$

Panel B: $\log \left(\right.$ Sizes $\left._{t}\right)=\alpha+\beta_{1}$ EOQ $_{t}+\beta_{2} \log \left(\right.$ Trades $\left._{t}\right)+\varepsilon_{t}$

Sizes $_{t}$ is the number of distinct quantities traded on day $t$. EOQ $E_{t}$ is an indicator taking the value 1 if day $t$ is in the last two weeks of a calendar quarter, else 0 . Trades $s_{t}$ is the number of transactions on day $t$. TradesSq is the squared number of transactions on day t. $\log \left(\operatorname{Sizes}_{t}\right)$ is the natural logarithm of the number of distinct quantities traded on day t. $\log \left(\operatorname{Trades}_{t}\right)$ is the natural logarithm of the number of transactions on day t. Period covered is January 3, 2000 to December 31, 2002. Number of observations varies by currency because of national holidays.

\begin{tabular}{|c|c|c|c|c|c|c|}
\hline & EUR & JPY & GBP & AUD & CHF & CAD \\
\hline \multicolumn{7}{|c|}{ Panel A: Quadratic } \\
\hline Constant & $\begin{array}{l}91.35^{\mathrm{a}} \\
(6.31)\end{array}$ & $\begin{array}{c}21.56^{\mathrm{b}} \\
(2.45)\end{array}$ & $\begin{array}{l}70.29^{\mathrm{a}} \\
(6.37)\end{array}$ & $\begin{array}{l}29.12^{\mathrm{a}} \\
(9.08)\end{array}$ & $\begin{array}{l}19.08^{\mathrm{a}} \\
(6.27)\end{array}$ & $\begin{array}{c}12.36^{\mathrm{a}} \\
(10.64)\end{array}$ \\
\hline End-of-Quarter & $\begin{array}{l}11.63^{\mathrm{c}} \\
(1.78)\end{array}$ & $\begin{array}{l}10.89^{\mathrm{a}} \\
(2.82)\end{array}$ & $\begin{array}{l}13.10^{\mathrm{a}} \\
(3.03)\end{array}$ & $\begin{array}{c}2.12 \\
(1.38)\end{array}$ & $\begin{array}{l}3.46^{\mathrm{b}} \\
(2.50)\end{array}$ & $\begin{array}{c}2.11^{\mathrm{a}} \\
(2.98)\end{array}$ \\
\hline Trades & $\begin{array}{l}0.34^{\mathrm{a}} \\
(7.60)\end{array}$ & $\begin{array}{c}0.50^{\mathrm{a}} \\
(13.48)\end{array}$ & $\begin{array}{c}0.28^{\mathrm{a}} \\
(4.07)\end{array}$ & $\begin{array}{c}0.27^{\mathrm{a}} \\
(6.07)\end{array}$ & $\begin{array}{c}0.27^{\mathrm{a}} \\
(6.24)\end{array}$ & $\begin{array}{c}0.39^{\mathrm{a}} \\
(13.58)\end{array}$ \\
\hline TradesSq & $\begin{array}{c}0.00 \\
(1.13)\end{array}$ & $\begin{array}{l}-0.00^{\mathrm{a}} \\
(-4.23)\end{array}$ & $\begin{array}{c}0.00^{\mathrm{a}} \\
(3.35)\end{array}$ & $\begin{array}{c}0.00^{\mathrm{c}} \\
(1.88)\end{array}$ & $\begin{array}{c}0.00^{\mathrm{a}} \\
(2.97)\end{array}$ & $\begin{array}{c}0.00^{\mathrm{a}} \\
(2.97)\end{array}$ \\
\hline \multicolumn{7}{|c|}{ Panel B: Logged } \\
\hline Constant & $\begin{array}{l}0.88^{\mathrm{a}} \\
(6.01)\end{array}$ & $\begin{array}{c}0.77^{\mathrm{a}} \\
(6.10)\end{array}$ & $\begin{array}{c}0.60^{\mathrm{a}} \\
(3.97)\end{array}$ & $\begin{array}{c}0.94^{\mathrm{a}} \\
(8.73)\end{array}$ & $\begin{array}{c}0.12^{\mathrm{c}} \\
(1.69)\end{array}$ & $\begin{array}{c}0.37^{\mathrm{a}} \\
(6.48)\end{array}$ \\
\hline End-of-Quarter & $\begin{array}{l}0.03^{\mathrm{c}} \\
(1.81)\end{array}$ & $\begin{array}{l}0.05^{\mathrm{b}} \\
(2.40)\end{array}$ & $\begin{array}{c}0.06^{\mathrm{a}} \\
(2.60)\end{array}$ & $\begin{array}{c}0.04^{\mathrm{c}} \\
(1.76)\end{array}$ & $\begin{array}{c}0.06^{\mathrm{a}} \\
(3.93)\end{array}$ & $\begin{array}{l}0.04^{\mathrm{b}} \\
(2.49)\end{array}$ \\
\hline $\log$ (Trades) & $\begin{array}{c}0.76^{\mathrm{a}} \\
(33.81)\end{array}$ & $\begin{array}{c}0.75^{\mathrm{a}} \\
(36.94)\end{array}$ & $\begin{array}{c}0.82^{\mathrm{a}} \\
(32.11)\end{array}$ & $\begin{array}{c}0.68^{\mathrm{a}} \\
(31.88)\end{array}$ & $\begin{array}{c}0.82^{\mathrm{a}} \\
(56.25)\end{array}$ & $\begin{array}{c}0.80^{\mathrm{a}} \\
(62.04)\end{array}$ \\
\hline Number of Obs & 769 & 761 & 770 & 772 & 768 & 771 \\
\hline
\end{tabular}

${ }^{\mathrm{a}}$ significant at $1 \%,{ }^{\mathrm{b}}$ significant at $5 \%,{ }^{\mathrm{c}}$ significant at $10 \%$ 


\section{Table A2}

\section{End-of-Quarter Impact on Price Impact: Basic and Extended Specifications}

This table reports the coefficient estimates, with t-statistics using robust standard errors in parentheses, of the following regression equation for each of the six major currencies.

Panel A: $\quad$ PriceImp $_{t}=\alpha+\beta_{1}$ EOQ $_{t}+\beta_{2}$ Volume $_{t}+\varepsilon_{t}$

Panel B: $\quad$ PriceImp $_{t}=\alpha+\beta_{1}$ EOQ $_{t}+\beta_{2}$ Volume $_{t}+\beta_{3}$ NonEOQ $_{t}+\beta_{4}$ PriceLevel $_{t}+\beta_{5}$ ImpVol $_{t}$

$$
+\beta_{6} \text { Period } 9 / 11_{t}+\beta_{7} \text { FutExp }_{t}+\beta_{8} \text { CBI }_{t}+\varepsilon_{t}
$$

PriceImp $\mathrm{I}_{\mathrm{t}}$ is the percentage price change divided by net order flow on day $t . \mathrm{EOQ}_{\mathrm{t}}$ is an indicator taking the value 1 if day $t$ is in the last two weeks of a calendar quarter, else 0 . Volume ${ }_{t}$ is the transaction volume in USD billions on day t. NonEOQ $\mathrm{t}$ is an indicator taking the value 1 if day $\mathrm{t}$ is in the last two weeks of a calendar month that is not the end of a calendar quarter, else 0 . PriceLevel $t_{t}$ is an indicator taking the value 1 if the currency crossed a major price level on day $t$, else $0 . \mathrm{ImpVol}_{\mathrm{t}}$ is the implied volatility for one-month currency options on day $\mathrm{t}$. Period $9 / 11_{t}$ is an indicator taking the value 1 if day $t$ is in the period $9 / 11 / 01$ to $9 / 14 / 01$, else 0 . FutExp $p_{t}$ is an indicator taking the value 1 if the related futures contract expired on day t, else $0 . \mathrm{CBI}_{\mathrm{t}}$ is an indicator taking the value 1 if there was central bank intervention on day t, else 0. Period covered is January 3, 2000 to December 31, 2002. Number of observations varies by currency because of national holidays.

\begin{tabular}{|c|c|c|c|c|c|c|}
\hline & EUR & JPY & GBP & AUD & CHF & CAD \\
\hline \multicolumn{7}{|c|}{ Panel A: Basic Specification } \\
\hline Constant & $\begin{array}{c}-0.00007^{\mathrm{c}} \\
(-1.91)\end{array}$ & $\begin{array}{c}0.00007 \\
(0.66)\end{array}$ & $\begin{array}{c}-0.00004 \\
(-0.50)\end{array}$ & $\begin{array}{c}0.00043 \\
(0.61)\end{array}$ & $\begin{array}{c}-0.00048^{\mathrm{c}} \\
(-1.70)\end{array}$ & $\begin{array}{c}0.00002 \\
(0.28)\end{array}$ \\
\hline End-of-Quarter & $\begin{array}{c}0.00003 \\
(1.24)\end{array}$ & $\begin{array}{c}0.00014^{\mathrm{c}} \\
(1.77)\end{array}$ & $\begin{array}{c}0.00009^{b} \\
(2.42)\end{array}$ & $\begin{array}{c}0.00087^{\mathrm{c}} \\
(1.67)\end{array}$ & $\begin{array}{c}0.00053^{\mathrm{a}} \\
(2.65)\end{array}$ & $\begin{array}{c}0.00020^{\mathrm{a}} \\
(2.78)\end{array}$ \\
\hline Volume & $\begin{array}{c}0.00001^{\mathrm{c}} \\
(1.69)\end{array}$ & $\begin{array}{c}-0.00002 \\
(-1.08)\end{array}$ & $\begin{array}{c}0.00001 \\
(0.41)\end{array}$ & $\begin{array}{c}-0.00057 \\
(-1.09)\end{array}$ & $\begin{array}{c}0.00060^{\mathrm{b}} \\
(2.09)\end{array}$ & $\begin{array}{c}-0.00000 \\
(-0.00)\end{array}$ \\
\hline \multicolumn{7}{|c|}{ Panel B: Extended Specification } \\
\hline Constant & $\begin{array}{c}0.00008 \\
(1.06)\end{array}$ & $\begin{array}{c}-0.00006 \\
(-0.16)\end{array}$ & $\begin{array}{c}0.00009 \\
(0.36)\end{array}$ & $\begin{array}{c}-0.00056 \\
(-0.37)\end{array}$ & $\begin{array}{c}-0.00055 \\
(-1.36)\end{array}$ & $\begin{array}{c}-0.00033 \\
(-0.61)\end{array}$ \\
\hline End-of-Quarter & $\begin{array}{c}0.00005 \\
(1.21)\end{array}$ & $\begin{array}{c}0.00012 \\
(1.48)\end{array}$ & $\begin{array}{c}0.00007^{b} \\
(2.32)\end{array}$ & $\begin{array}{c}0.00095 \\
(1.35)\end{array}$ & $\begin{array}{c}0.00054^{\mathrm{b}} \\
(2.37)\end{array}$ & $\begin{array}{c}0.00014 \\
(1.24)\end{array}$ \\
\hline Volume & $\begin{array}{c}-0.00000 \\
(1.44)\end{array}$ & $\begin{array}{c}-0.00002 \\
(-1.02)\end{array}$ & $\begin{array}{c}0.00001 \\
(0.43)\end{array}$ & $\begin{array}{c}-0.00060 \\
(-1.12)\end{array}$ & $\begin{array}{c}0.00060^{\mathrm{b}} \\
(2.10)\end{array}$ & $\begin{array}{c}0.00000 \\
(0.06)\end{array}$ \\
\hline $\begin{array}{l}\text { Non-EOQ } \\
\text { End-of-Month }\end{array}$ & $\begin{array}{c}0.00004 \\
(1.03)\end{array}$ & $\begin{array}{c}-0.00003 \\
(-0.42)\end{array}$ & $\begin{array}{c}-0.00008 \\
(-0.88)\end{array}$ & $\begin{array}{c}0.00009 \\
(0.14)\end{array}$ & $\begin{array}{c}-0.00014 \\
(-0.69)\end{array}$ & $\begin{array}{c}-0.00006 \\
(-0.89)\end{array}$ \\
\hline PriceLevel & $\begin{array}{c}-0.00003 \\
(-1.56)\end{array}$ & $\begin{array}{c}0.00002 \\
(0.36)\end{array}$ & $\begin{array}{c}0.00001 \\
(0.41)\end{array}$ & $\begin{array}{c}0.00041 \\
(0.75)\end{array}$ & $\begin{array}{c}0.00013 \\
(0.97)\end{array}$ & $\begin{array}{c}-0.00007 \\
(-0.82)\end{array}$ \\
\hline Implied Volatility & $\begin{array}{c}-0.00001 \\
(-1.31)\end{array}$ & $\begin{array}{c}0.00001 \\
(0.34)\end{array}$ & $\begin{array}{c}-0.00001 \\
(-0.40)\end{array}$ & $\begin{array}{c}0.00006 \\
(0.40)\end{array}$ & $\begin{array}{c}-0.00002 \\
(-0.05)\end{array}$ & $\begin{array}{c}0.00007 \\
(0.75)\end{array}$ \\
\hline 9/11 Period & $\begin{array}{c}0.00013^{\mathrm{c}} \\
(1.92)\end{array}$ & $\begin{array}{c}-0.00005 \\
(-0.55)\end{array}$ & $\begin{array}{c}-0.00004 \\
(-0.62)\end{array}$ & $\begin{array}{c}-0.00049 \\
(-0.49)\end{array}$ & $\begin{array}{c}0.00230 \\
(1.14)\end{array}$ & $\begin{array}{c}-0.00006 \\
(-0.90)\end{array}$ \\
\hline Futures Expiration & $\begin{array}{c}0.00003 \\
(1.51)\end{array}$ & $\begin{array}{c}-0.00010^{\mathrm{c}} \\
(-1.83)\end{array}$ & $\begin{array}{c}-0.00006^{\mathrm{a}} \\
(-2.65)\end{array}$ & $\begin{array}{c}-0.00005 \\
(-0.14)\end{array}$ & $\begin{array}{c}-0.00044^{\mathrm{a}} \\
(-2.71)\end{array}$ & $\begin{array}{c}-0.00010 \\
(-1.19)\end{array}$ \\
\hline $\begin{array}{l}\text { Central Bank } \\
\text { Intervention }\end{array}$ & $\begin{array}{c}0.00002 \\
(0.53)\end{array}$ & $\begin{array}{c}0.00000 \\
(0.10)\end{array}$ & $\begin{array}{c}-0.00001 \\
(-0.01)\end{array}$ & $\begin{array}{c}-0.00073 \\
(-1.10)\end{array}$ & $\begin{array}{c}-0.00034^{\mathrm{c}} \\
(-1.93)\end{array}$ & $\begin{array}{c}0.00055 \\
(0.94)\end{array}$ \\
\hline Number of Obs & 769 & 761 & 770 & 772 & 768 & 771 \\
\hline
\end{tabular}

\footnotetext{
${ }^{\mathrm{a}}$ significant at $1 \%,{ }^{\mathrm{b}}$ significant at $5 \%,{ }^{\mathrm{c}}$ significant at $10 \%$
} 